\title{
CURRENT PERSPECTIVES OF SENTINEL LYMPH NODE DISSECTION AT THE TIME OF RADICAL SURGERY FOR PROSTATE CANCER.
}

Gavish Munbauhal ${ }^{1}$, Thomas Seisen ${ }^{1,2}$, Florie Gomez $^{3}$, Benoit Peyronnet ${ }^{4}$, Olivier Cussenot $^{2,5}$, Shahrokh F. Shariat ${ }^{6}$, Morgan Rouprêt ${ }^{1,2 *}$

${ }^{1}$ Academic Department of Urology of La Pitié-Salpétrière, Assistance-Publique Hôpitaux de Paris, Faculté de Médecine Pierre et Marie Curie, University Paris 6, 75013 Paris, France

${ }^{2}$ Institut Universitaire de Cancérologie, Pierre et Marie Curie, University Paris 6, GRC n 5, CeRePP/ONCOTYPE-URO, 75013 Paris, France

${ }^{3}$ Department of Urology, CHC Liege, Liège, Belgium

${ }^{4}$ Academic department of Urology, CHU Rennes and University of Rennes, France

${ }^{5}$ Academic Department of Urology of Tenon, Assistance-Publique Hôpitaux de Paris; Faculté de Médecine Pierre et Marie Curie, University Paris 6, 75013, Paris, France

${ }^{6}$ Academic Department of Urology and Comprehensive Cancer Centre, Vienna General Hospital, Medical University of Vienna, Vienna, Austria

Word count: Abstract (215), Manuscript (4978)

Tables (4)

${ }^{*}$ Corresponding author: Morgan Rouprêt, MD, PhD

Academic Department of Urology

Pitié-Salpêtrière Hospital

47-83 boulevard de l'hôpital, 75013 Paris, France

morgan.roupret@psl.aphp.fr 


\section{CURRENT PERSPECTIVES OF SENTINEL LYMPH NODE DISSECTION AT THE TIME OF RADICAL SURGERY FOR PROSTATE CANCER.}

\section{ABSTRACT}

The sentinel lymph node dissection (SLND) concept relies on the accurate detection of primary nodal landing sites and could represent a major advancement towards accurate, non-invasive pelvic staging in prostate cancer (PCa). Different iterations of the technique have now been validated and reproduced mostly in large-volume centres. The existing evidence denotes the feasibility and sensitivity of SLND, with encouraging pre- and intraoperative detection rates of $98 \%$ and $96 \%$. Yet, current surgical practice mandates a backup template dissection due to a false negative rate, up to $7.1 \%$, of tracer-guided surgery. In practice, SLND failed to achieve nodal detection in up to $20 \%$ of pelvic sidewalls. Despite scarce validated evidence, current consensus mainly attributes these false negative cases to altered prostatic drainage secondary to malignant obliteration of lymphovascular structures. In parallel, multiple SLND studies have highlighted the complex and variable drainage pathways from the prostate, furthering the established anatomical atlases. The most promising approach may therefore rely in magnetic nanoparticles and PCa-targeting ligands. However, in the absence of a clear sentinel node or region for the prostate, formal SLND is difficult to integrate in routine surgical practice for now. As such, tracer-guided dissection is only used as a complementary intervention to highlight first- echelon nodes and aberrant lymphatic pathways found beyond the commonly adopted pelvic lymphadenectomy templates.

Keywords (MeSH): Prostatic Neoplasms; Sentinel Lymph Node Biopsy; Lymph Node Excision; Lymphoscintigraphy; Radioactive Tracers; Indocyanine Green; Fluorescence. 


\section{INTRODUCTION}

Accurate pelvic staging remains one of the most significant prognostic factors that guide contemporary management of localized prostate cancer (PCa). As such, current international guidelines advocate the use of extended pelvic lymph node dissection (ePLND) in intermediate- and high-risk PCa management if the preoperative probability of nodal spread is greater than $5 \%[1,2]$. However, a recent multicentre analysis of patients undergoing radical prostatectomy (RP) with ePLND for clinically localised $\mathrm{PCa}$ $(n=6,678)$ has reported a lymph node invasion (LNI) rate up to only $11.5 \%$. In addition, subgroup analysis of those with pT3 disease showed LNI in no more than $12.5 \%$ of cases, which was nonetheless, a strong predictor of 5-year biochemical recurrence on multivariable analysis [3].

From a clinical perspective, this adds to the well-established evidence that systematic ePLND could be overtreating the vast majority of patients diagnosed with localised malignancies and risks an unnecessary burden of complications $[2,4,5]$. However, the unreliability of clinical and radiological staging methods in detecting microscopic lymphovascular invasion means that simple wait-and-watch policies might carry a significant risk of identifying nodal involvement when curative treatment is no longer possible.

Despite years of controversy, it is now accepted that limited LND is inadequate for PCa management, as $50 \%$ of metastatic nodes can been found outside the obturator fossa [2]. Consequently, elective sentinel LND (SLND) has been proposed as an alternative to ePLND for accurate lymphovascular staging while avoiding the invasiveness and morbidity of large dissection templates. The large super-specialist PCa centres in The Netherlands [6-9], Germany [10-12] and France [13,14] have spearheaded SLND research and more than 50 articles have been published in the last decade [10-14]. However, the heterogeneity of study designs and a general lack of consensus over 
protocols and reporting standards make such evidence challenging to interpret. Contemporary overview of SLND literature in PCa has highlighted its feasibility and sensitivity but does not provide conclusive evidence to validate the benefit of SLND [1518]. Against this backdrop, we aim to provide a comprehensive review of the current literature to summarise the evidence for the use of SLND in PCa management. 


\section{TECHNIQUE OF SENTINEL LYMPH NODE DISSECTION}

\section{Concept}

SLND is based on the assumption that lymphovascular spread is predictable and that malignant cells will spread sequentially to a specific single SLN or group of SLN (firstechelon) prior to subsequent drainage into higher-tier lymphatics (second- and thirdechelon nodes) [18]. SLND can thus detect patient-specific lymphatic tree outside generic dissection templates. Logically, invasion of SLN indicates the need for further dissection, while clear SLN would preclude any additional LND.

Within the field of onco-urology, SNLD was pioneered by Cabanas et al who reported on a lymphangiographic study of nodal metastases from penile cancer in 1977 [19]. However individual variations in anatomy and lymphatic drainage patterns meant that block dissections relying on static landmarks led to high false-negative rates and this approach was abandoned. Following technical advances in the visualisation of individual lymphatic drainage patterns in melanoma, breast and penile cancer in the 1990s, Wawroschek et al adapted SLND to prostate cancer staging $[18,20]$. Subsequently, multiple groups have validated the feasibility of the technique and the focus has now shifted onto refining its diagnostic accuracy.

\section{Technique evolution}

\section{Conventional sentinel lymph node dissection}

In 1992, Morton et al. established the feasibility of SLND using a blue dye to identify individual nodes in a cohort of melanoma patients [18]. The technique was rapidly taken up in both melanoma and breast surgery and the protocol was soon furthered by adding a radioisotope tracer- Technetium- $99 \mathrm{~m}\left({ }^{99 \mathrm{~m}} \mathrm{Tc}\right)$. This enabled the intra-operative examination of lymphatic regions using a gamma probe and reduced the inaccuracy of 
LND. Until then, nodal dissection was only based on pre-operative planar lymphangiography and anatomical templates.

Early evaluation of blue dye for prostate cancer highlighted significant drawbacks due to the location of pelvic nodal regions. In addition to difficulty in visually detecting nodes in the deeper pelvis, nodal manipulation led to significant leakage into the operating field, making visual detection of individual nodes impossible [16]. Hence ${ }^{99 m}$ Tc-labelled nanocolloids have been the mainstay of SLND for PCa for over 15 years. The SLN protocol consisted of pre-operative imaging by planar static lymphoscintigraphy and Single Photon Emission Computer Tomography (SPECT) or fusion SPECT/CT in addition to intraoperative identification of nodes using handheld or laparoscopic gamma probes.

\section{Fluorescence imaging}

The use of radiotracers in SLND has, however, recently been put into question despite the high sensitivity of ${ }^{99 m}$ Tc-nanocolloids for nodal detection in PCa [21-24]. First- and second-echelon nodes often cannot be differentiated due to technical difficulty in identifying the draining vessels. In open surgery specifically, the distance between the gamma camera and injection site decreases special resolution while the slow drainage pattern is not accurate on preoperative planar lymphoscintigraphy. This means that all radioactive nodes have to be removed [10].

Other limitations to the use of radiotracers in SLND first include the need of significant input from nuclear medicine in terms of equipment and experienced staff: scheduling of the pre-operative step, as well as the handling and disposal of radioisotopes add to the cost- and time-factor of RP pathways. Second, there is an associated health risk for

staff and patients exposed to radioactive ${ }^{99 m} \mathrm{Tc}$, in spite of its 6 -hour half-life $[21,23]$. Third, interruptions in supply and intermittent closure of the five research reactors able 
to produce the parent compound in the late 2000 s led to a significant shortage of ${ }^{99 m} \mathrm{Tc}$ $[21,24]$. Finally, the advent of robotic RP has also impacted on the use of large gamma cameras and prompted a shift towards more integrated imaging modalities.

The need for an innovative approach highlighted indocyanine green (ICG) as a potential replacement. ICG is a non-radioactive, non-specific contrast agent, which has been used for 50 years to determine hepatic clearance, cardiovascular function, and ophthalmic angiography. It boasts an impressive safety profile with few reported allergic reactions to its iodine content and undergoes rapid hepatic metabolisms and excretion in bile [25]. Free-ICG has a molecular weight of only $774 \mathrm{Da}$ and binds readily to albumin to form complexes that are significantly smaller than ${ }^{99 m}$ Tc-nanocolloids. Hence, ICG complexes could potentially demonstrate superior flow through the partiallyobstructed lymphovascular structures affected by tumour spread [22]. At high concentration, the ICG fluorophore is dark green and generates similar lymphovascular staining patterns as blue dye, which enables visual detection of superficial lymph vessels and nodes $[22,25]$. In pelvic SLND, ICG is diluted to a pale green solution at concentrations between $0.05 \mathrm{mg} / \mathrm{ml}$ and $2.5 \mathrm{mg} / \mathrm{ml}$ prior to prostatic injection $[6,7,23,26-$ 30] and activated to emit near-infrared fluorescence (NIRF) by an excitation light, itself in the near-infrared (NIR) spectrum. In a prospective study comparing ICG to ${ }^{99 m} \mathrm{Tc}$ in melanoma patients, Stoffels et al demonstrated a tissue penetrance of only $10-15 \mathrm{~mm}$ with free-ICG, preventing detection of lymphatic pathways extending to deep tissues [22]. This is attributed to ICG's weak intrinsic fluorescence and high tissue attenuation of low-energy NIRF compared to gamma energy from radiotracers.

In 2011, Inoue et al reported on the first study introducing free-ICG imaging to open RP in 14 patients [23]. Despite proving procedural feasibility, their study showed that the 2 patients with nodal metastases were the only ones where ICG NIRF could not detect lymphatic pathways. Jeschke et al investigated the concurrent use of both ${ }^{99 m} \mathrm{Tc}$ and 
ICG NIRF in laparoscopic RP for intermediate- and high-risk PCa in an attempt to distinguish radiotracer-detected first echelon nodes from second and third tiers [31]. ${ }^{99 \mathrm{~m}} \mathrm{Tc}$-albumin was injected 18 hours before surgery while ICG injections occurred intraoperatively or immediately before draping the patient. The study proved that realtime ICG NIRF could be used for a more dynamic mapping of lymphatic drainage pathways afferent to and efferent from the SLN detected by ${ }^{99 m} \mathrm{Tc}$. Importantly, they also demonstrated that half of the patients had SLN detected exclusively by fluorescence, two patients had nodes detected by ${ }^{99 \mathrm{~m}} \mathrm{Tc}$ only while the remaining 11 patients had nodes detected by both modalities. They later dispensed with ${ }^{99 \mathrm{~m}} \mathrm{Tc}$-colloid in a study with a larger proportion of high-risk PCa patients and reported $97.7 \%$ sensitivity of free ICG-guided PLND with only 1 case of procedural failure giving complete non-visualisation in a node-positive patient [26]. However, the rapid distribution of the small ICG molecules in the lymphatic system (5-30 minutes $[23,26,28,30,31])$ combined to low tissue penetrance strictly restricted ICG use to the intraoperative phase, through prostatic injection under direct vision or immediately preceding laparotomy/laparoscopy.

\section{Hybrid fluorescent-radiotracer}

Van der Poel et al were the first to demonstrate the feasibility of a hybrid fluorescentradiotracer in a study of 11 patients undergoing robotic RP[9]. ICG combined to ${ }^{99 \mathrm{~m}} \mathrm{TC}$ nanocolloid formed a hybrid complex that could be imaged preoperatively using SPECT and intraoperatively using a laparoscopic NIR camera. 55\% of SLN could be visualised after $15 \mathrm{~min}$ and $91 \%$ after 2 hours. Compared to free-ICG molecules, the larger hybrid complex was not cleared rapidly from the lymphatic system, and accumulated in lymph nodes due to phagocytosis [15]. 
Direct comparison of the hybrid complex to conventional ${ }^{99 \mathrm{~m}} \mathrm{Tc}$-nanocolloid and simple blue dye was examined in melanoma and penile cancer SLND [32]. Fluorescence visualisation with hybrid ICG- ${ }^{-99 m} \mathrm{Tc}$-nanocolloid offered a higher special resolution than gamma cameras, unimpeded by background radiation from the injection site or spillage. $95 \%$ of nodes could be localised intraoperatively by NIRF, $94 \%$ by a portable gamma probe and only $54 \%$ by blue dye. The 4 nodes missed by NIRF demonstrated ex vivo fluorescent activity using a more sensitive imaging system. All fluorescent nodes exhibited ex vivo radioactivity, highlighting the stability of the hybrid complex at a median 5 hours (range 4-23) after injection [32]. The Dutch group furthered their experience in 40 robotic RP patients, demonstrating improvement of intraoperative fluorescence with novel hybrid tracer formulation and an upgrade to the fluorescence imaging system [7].

Further integration into the da Vinci Surgical System was evaluated both with free-ICG [28] and the hybrid tracer [6] using the in-built Firefly NIRF technology. The surgeon obtained an intuitive fluorescent overlay to his view of the operating field by switching between white light and NIRF imaging autonomously at his console. Under white light, NIRF is invisible to the surgeon's eye and does not corrupt the operating field.

Analysis of fluorescence imaging in open procedures has been superseded by multiple studies from high-volume centres focusing on minimally-invasive approaches. Yet, two more contemporary studies highlight the ongoing feasibility and improved outcomes of NIRF-augmented open surgery $[29,30]$. The potential for greater uptake in open RP is highlighted by Van den Berg et al's recent report on a modified version of the conventional handheld fluorescence camera [33]. Akin to the robotic overlay imaging technology, the modified device displays the coloured fluorescence image on a realtime gray-scale background of the operating field. Given that their prototype functions under ambient operating lights, the surgeon can continually switch between white light 
and NIRF light to achieve near-continuous fluorescence guidance while dissecting lymphovascular structures.

\section{Tracer injection site and technique}

As opposed to the SLND for other malignancies (eg breast cancer or malignant melanoma), intratumoral or peritumoral tracer injection is not readily achievable for $\mathrm{PCa}$ due to the low accuracy of ultrasound in identifying the malignant foci within the prostate $[10,31,34,35]$. Moreover, PCa is itself known to be multifocal within the gland, undermining accurate preoperative localisation of all the tumour deposits by conventional imaging or random biopsies [24,31,34]. Given that prostatic adenocarcinoma is thought to arise from the peripheral zone of the gland, current consensus is to target the peripheral parenchyma non-specifically with transrectal ultrasound(TRUS)-guided injections[35].

Buckle et al noted that injection of hybrid tracer into the peripheral zone of the prostate yielded better nodal visualisation compared to the central zone while the peripheral midgland area was superior compared to the apex or base [35]. Histopathological analysis of paraffin-embedded prostate specimens in that cohort located $84 \%$ of tumour tissue in the posterior half and peripheral zone [35]. As such, the authors hypothesised that the denser peripheral tissue generates a higher interstitial fluid pressure after tracer injection, enhancing lymphatic drainage.

Manny et al compared percutaneous, TRUS-guided and cystoscopic ICG injection techniques in prostatic SLND and reported that robot-guided percutaneous injection was the most cost- and time-effective option [28]. In addition to preventing accidental extraprostatic dye spillage, prostatic bleeding or infection from TRUS-guided injections, it did not require additional equipment nor divert the operation's course. A randomised comparative study from The Netherlands Cancer Institute (N12IGP, NL41285.031.12) 
on intraprostatic vs intratumoural tracer deposits is underway $[7,15]$. Meanwhile, the traditional concept of SLND can hardly apply to PCa as current techniques map the lymphatic drainage of the whole gland and not the tumour specifically. 


\section{PROSTATE SENTINEL LYMPH NODE DETECTION BY ANATOMICAL REGION}

In 2008, Mattei et al provided the first comprehensive map of prostate SLN in 34 patients [36]. SLN distribution was shown to extend significantly beyond the traditional templates (obturator, external iliac and internal iliac nodes). The authors proposed an improved ePLND template including common iliac nodes to cover $75 \%$ of all SLNs. This anatomical template was seconded by Ganswindt's SPECT-derived anatomical atlas of 324 SLNs in $61 \mathrm{PCa}$ cases [37].

In a landmark study, Jeschke et al characterised 3 distinct prostate drainage pathways in real-time [31]; 1) following the seminal duct then crossing the medial umbilical ligament inferiorly to reach external iliac nodes, 2) arising dorsal to the bladder, coursing around the medial umbilical ligament, along internal and common iliac vessels to reach the para-aortic and presacral nodes, 3) running between the medial umbilical ligament and ureter, up to the common iliac vessels to reach presacral nodes or bypassing those to reach para-aortic nodes [31].

We summarised the reported findings from the different studies in Table 1 $[6,7,11,13,14,26,28-31,34,38]$. In line with previous templates, most SLNs could be identified in the obturator, external/internal iliac and common iliac regions. However, a median $6 \%, 3 \%$ and $1.2 \%$ of detected nodes originated from the presacral, pararectal and paraaortic regions respectively. In an attempt to catch $96 \%$ of nodal spread, Joniau et al recommended new standard ePLND template to include presacral regions [34]. They also stressed that despite significant drainage to the common iliac regions (19\% preoperatively, $14 \%$ intraoperatively), removal of this nodal region gave $\leq 1 \%$ of metastatic nodes compared to $5 \%$ to the presacral region. Interestingly, two separate reports each highlighted 'new' nodal regions; Manny et al noted that $13 \%$ of SLNs were in a preprostatic zone [28], while in the Swiss mapping study, $12 \%$ of SLNs were found in the fossa of Marcille [30]. 
The Tübingen group's report on 463 patients demonstrated that $59 \%$ of SLN regions were identified beyond the obturator fossa, containing $51 \%$ of metastasis [11]. Further studies have reported that up to $73 \%$ of SLNs could be detected beyond the obturator fossa $[13,14,38]$. These findings supplement the evidence-base in favour of an ePLND as the minimum dissection extent. Yet, in a large series of 2020 cases, Holl et al revealed that at least $7.2 \%$ of the 600 metastatic nodes were found outside an ePLND incorporating common iliac dissection [10]. Notably, pararectal and presacral regions each contained $2.8 \%$ of the nodes with the rest distributed in the paravesical region. Table 2 summarises the surgical relevance of metastasis location as reported by 16 studies $[4,7-11,13,14,26,28,29,34,38-41]$. Rousseau et al $(n=203)$ found that in 35 node-positive patients, most of the metastatic SLNs could be found in the internal iliac region despite equal distribution of all nodes to the obturator, internal and external regions [14].

In a 2015 report from Japan on the feasibility of free-ICG in open RP $(n=65)$, Yuen et al visualised three distinct pathways [29], analogous to the European findings a few years earlier [31]. $78 \%$ of pelvic sidewalls contained a paravesical pathway leading to obturator nodes to the bifurcation of external and internal iliac vessels. In $50 \%$, an internal route could be traced along the inferior vesical artery draining into the internal iliac region. Lastly, $21 \%$ showed a lateral path to the obturator region either directly, through the obturator foramen or branching off the internal route [29]. 3 of 6 patients with metastases had positive nodes to the internal iliac, in accordance with previous reports. This apparent association of prostate drainage and metastatic spread to the internal nodes has been demonstrated previously and could have a significant impact on the relevance of SLND $[10,14,23,34,39,42]$.

This could stem from the location of the tumour and tracer deposit within the gland. Buckle et al showed that when tracer deposition was mostly to one side of the prostate, 
more SLN could be detected in the ipsilateral hemipelvis [35]. Tracer deposits in the prostate base correlated with SLN detection in the common iliac region, while a focused deposit to the apex flowed to a paracaval node. These results supported earlier findings from Weckermann et al who showed in 564 patients that unilateral prostate cancer metastasizes 'preferentially' to ipsilateral pelvic nodes [42]. However, proven instances of bilateral metastases of unilateral malignancy, visualization of cross-over lymphatics and the difficulty in accurately staging unilateral disease support the need for bilateral pelvic dissection irrespective of an unilateral visualisation of primary $P C a[14,30,35,42]$. The ongoing Dutch study (N12IGP, NL41285.031.12) on tracer deposition techniques may shed more light on this matter $[7,15]$. 


\section{DIAGNOSTIC PERFORMANCE OF TRACER-GUIDED SURGERY IN PROSTATE}

\section{CANCER}

\section{Conventional techniques}

Since the inception of SLND in prostate cancer, its diagnostic accuracy has been the mainstay of research. Modification of the early open technique was pioneered by the Augsburg group, who demonstrated that drainage patterns and SLNs could be detected in up to $98.2 \%$ of 2020 patients with clinically localised disease[10]. Preoperative planar lymphoscintigraphy detected drainage patterns in $97.6 \%$ of patients while intraoperative SLN detection using a handheld probe was successful in $98 \%$ of cases[10]. As per their previous experience in risk-stratification of low-risk patients, they concluded that those with pre-operative Gleason up to $3+4$ could receive SLND only. A score greater than $4+3$ required additional backup ePLND, while Gleason $>8$ patients underwent ePLND only. $16.7 \%$ patients had lymph node invasion (LNI) and they reported overall false negative rates of $5.9 \%$ per patient and $5.3 \%$ per positive node. These figures increased to $14 \%$ and $5.3 \%$ respectively in the patient subgroup with pathological Gleason $>8$ disease.

Tables 3 and 4 summarise the characteristics and diagnostic outcomes of the main studies reporting on the different tracer modalities $[4,6-14,23,24,26,28-31,34,38-$ 41,43 ]. The median pre-operative detection rate across 15 studies was $97.6 \%$ (Range 81-100) and the median intraoperative detection in 21 studies was 96.1\% (Range 69100). Overall, combination of both imaging identified SLNs in $97.8 \%$ of patients (Range 76-100). Preoperatively, patients were found to have bilateral and unilateral SLN visualisation in $80 \%$ (Range 53-100) and 16\% (Range 11-32) of cases respectively. In studies using free-ICG as the only tracer, median intraoperative fluorescence detection was $97 \%$ (Range $76-97$ ) $[23,26,28-31]$. Manny et al showed that despite detection rates of $76 \%$, ICG remained $100 \%$ sensitive to metastatic nodes and suggested an alternative 
approach in which high-risk patients would undergo limited template dissection followed by NIRF-guided dissection of any remaining hot node [28]. However, shallow tissue penetrance of NIRF and the inability to locate nodes before surgery means that NIRFaugmented surgery alone cannot lead the SLND, nor replace PLND.

In addition, 46 false negative SLND cases were reported in 16 studies, with an overall median false negative rate (FNR) of $7.1 \%$ (mean $13.9 \%$, range $0-100 \%$ ). Jeschke et al reported on missing tracer activity within pelvic sidewalls in up to $19 \%$ of their cases, including one patient with LNM found by template dissection [41]. The main cause of false negative results so far has been attributed to obstruction or obliteration of lymphovascular ducts and nodes by tumour cells. This hypothesis was partially discredited by Joniau et al's report on 74 patients where superextended PLND had showed that $51 \%$ of macrometastases (>2mm deposit) were first-echelon nodes [34]. The authors noted that over $45 \%$ of these positive nodes had sufficient radioactive tracer uptake for detection. No absolute qualitative consensus has been achieved regarding the sensitivity of uptake and resulting detection within macrometastases. Further explanations include unresolved tissue inflammation or tissue changes from previous treatment (transurethral resections; radiotherapy) causing diversion of lymph flow or aberrant diffusion through the prostate. In cases using free-ICG, it is possible that the small tracer molecules are cleared completely from the afferent lymphatics and first-echelon node to reach higher tiers by the time NIRF detection is done [9]. In addition, endoprostheses and extrinsic ferromagnetic objects are liable to affect the performance of SPIO detection using intraoperative magnetometers [24,44].

Interestingly, the median number of dissected SLN as reported in 18 studies was 4 (Range 2-15) $[4,6,7,9-14,24,26,29-31,34,38,41,43]$ while total number of dissected nodes after backup PLND in 21 studies was 16 (Range 7-35) [4,6,7,9-14,23,24,26,28-31,34,38-40,43]. Pathological evaluation of excised nodes varies minimally across different centres. Following 
macroscopic examination, specimens are fixed in formalin and embedded in paraffin prior to step sections and staining with haematoxylin-eosin. Serial sectioning into thinner slices and immunohistochemistry using anti-cytokeratin antibody is essential for the detection of micrometastatic deposits $(\leq 2 \mathrm{~mm})$ in negative or inconclusive cases[10-13,34,38,41,42]. The median LNI rate was $18.2 \%$ (mean 23.1; range 5.6-50). Amongst growing interest into the prognostic value of micrometastases (MM) in $\mathrm{PCa}$, Jeschke et al reported on 10 microscopic deposits in 26 positive SLN [41] while Bastide et al reported the presence of MM in up to $42 \%$ of their positive cases [13]. In a large cohort of 1229 patients, Winter et al showed that $17.6 \%$ of all nodes removed contained MM, while a fifth of node-positive patients had MM deposits only. MM was present in $19 \%$ of all positive SLNs, in addition to $14 \%$ of non-SLNs, while $20 \%$ of all MM were found in non-SLN only [12]. In the same year, Rousseau et al reported that 14 of 35 node-positive patients had MM, 9 of those being confined to SLN [14]. Staník et al[38] illustrated that in a cohort of 80 intermediate- and high-risk patients, SLND with serial histopathological sections and immunohistochemistry enabled accurate staging in an additional $28 \%$ of patients compared to SLND with standard histopathological examination.

\section{Innovative techniques}

In addition to the previously described tracers to detect SLNs, other techniques with varying diagnostic performance have been proposed. Specifically, Häcker et al demonstrated that $\left[{ }^{18} \mathrm{~F}\right]$ Fluorocholine Positron Emission Tomography-Computerized Tomography (PET-CT) failed to visualise metastases in 9 of 10 node-positive cases [40]. They highlighted that the $4 \mathrm{~mm}$ resolution of PET-CT missed nodes with a diameter of $0.2-8.0 \mathrm{~mm}$, while two false positive cases resulted from slight nodal inflammation. In addition, Winter et al reported on the first human study of the use of superparamagnetic iron oxide (SPIO) nanoparticles as a magnetic SLN tracer [24]. SPIO particles have 
been previously validated to increase the sensitivity of conventional preoperative MRI from 45 to $100 \%$ and was found to be $97 \%$ specific [45]. In the current pilot study, an intraoperative handheld magnetometer was used instead. It detected SLNs in 17 of 19 patient and all the positive nodes, leading to a detection rate of $90 \%$ and $100 \%$ metastatic sensitivity [24]. Further validation is however required for this technique.

\section{Disease recurrence setting}

Vermeeren et al proved that SLND was feasible in ten patients with locally recurrent disease following external beam radiotherapy, hormonal treatment, brachytherapy, highintensity focused ultrasound or transurethral resection [46]. ${ }^{99 m}$ Tc-nanocolloid gave a detection rate of $100 \%$ for lymphatic drainage, while eight cases showed bilateral drainage to para-iliac nodes. However, $80 \%$ of patients had SLNs outside the para-iliac region and comparison to an untreated control group $(n=70)$ showed that treatment increased the SLN detection in aberrant regions $(p=0.01)$. 


\section{OUTCOMES OF SENTINEL LYMPH NODE DISSECTION}

\section{Oncological performance}

Only scarce evidence surrounding biochemical recurrence $(B C R)$ is available for SLND. This is additionally mostly limited to studies using only free-ICG or ICG- ${ }^{99 m}$ Tc hybrid. Specifically, Hruby et al reported their node-positive patients noting that 8 of 13 patients achieved a PSA $<0.1 \mathrm{ng} / \mathrm{ml}$ while two were lost after a 6-week follow-up [26]. In a followup period of 6 to 27 months, Yuen et al found BCR in 2 patients, of whom only one was node-positive [29]. In a comparative study on ICG technique, Kleinjan et al reported on 3 BCR cases at 38 months total follow-up in subgroups of cases not using their novel tracer formulation nor an improved imaging system [7]. However, given that a back-up extended or superextended dissection is carried out in most studies that use SLND as a staging intervention, it is not possible to characterise the BCR rates of SLND specifically. Moreover, neoadjuvant androgen deprivation therapy (ADT) is known to reduce the sensitivity of micrometastatic detection during routine histopathological examination. Fukuda et al reported that serial step sectioning with immunohistochemical staining was necessary to detect $56 \%$ of micrometastatic deposits in a neoadjuvant ADT subgroup [39]. Hence it is possible in some cases that false negative histopathological analysis would lead to BCR due to factors extrinsic to the SLND.

Muck et al reported on the only study to assess the clinical outcomes of patients following SLND [47]. 140 of their patients (17.1\%) were found to be node-positive after RP combined with standard PLND to the obturator and external iliac vessels and an extended SLND of the pelvis. Overall, $84 \%$ of LN-positive patients received ADT postoperatively. Mean biochemical recurrence-free survival (RFS), cancer-specific survival (CSS), overall survival (OS) and RFS after secondary treatment were 4.7, 8.8, 8.1 and 7.0 years respectively. Overall 5-year RFS, CSS and OS were $35 \%, 89 \%$ and $82 \%$ 
respectively. Interestingly, in the subgroup of patients with mere presence of micrometastases, 5-year CSS and OS were $100 \%$ and $92 \%$ respectively.

\section{Complications}

The feasibility of SLND for PCa has been well established, yet there is scarce data available on its safety profile as well. Three cases of septic prostatitis have been reported after radiotracer injection, requiring parenteral antibiotics and a change in the operative plan $[11,41]$. Following gamma probe-guided dissection of a paraaortic SLN, one patient developed retroperitoneal bleeding requiring surgical revision [43]. An external iliac vein injury was also reported during initial laparoscopic SLND[41].

In most studies, the reported complications stem from backup PLND. Overall, 111 backup PLND-related complications were reported, notably fifty-seven (51\%) lymphoceles, eight (7\%) lower leg oedema, seven (6\%) deep vein thromboses, four (4\%) each of iliac vessel injury, ureteral injury, urinary tract infection, three (3\%) each of pulmonary emboli, pelvic nerve injury, penoscrotal oedema $[6,7,11,14,26,29,34,40,41,43]$. 


\section{FUTURE TRENDS}

The need for a tumour-targeted approach has driven the emergence of molecular ligands with a higher specificity to $\mathrm{PCa}$. Currently the most promising target for molecular probes is the prostate-specific membrane antigen (PSMA) transmembrane glycoprotein. However, radiolabeled-PSMA ligands remain at an experimental stage in diagnostic imaging of the prostate, and there has been little experience in their integration into SLND [48-50].

Compared to other tissue cells that express the same protein, PSMA is significantly overexpressed on $90-100 \%$ of local and metastatic PCa cells with propensity for highgrade, metastatic disease [48,50-52]. Afshar-Oromieh et al demonstrated that for recurrent PCa, the extracellular PMSA inhibitor ${ }^{68} \mathrm{Ga}-\mathrm{PSMA}$ PET/CT was more sensitive than conventional ${ }^{18} \mathrm{~F}$-choline PET/CT in detecting more and smaller nodes even at low PSA levels [52]. However, when compared to a backup ePLND, ${ }^{68}$ Ga-PSMA PET/CT only achieved $33 \%$ sensitivity and $100 \%$ specificity in detecting LNM prior to RP in a high-risk cohort [53]. The authors of this latter study highlighted a significant size difference in ${ }^{68} \mathrm{Ga}-\mathrm{PSMA}$ PET/CT-detected vs undetected nodes (median $13.6 \mathrm{~mm}$ vs $4.3 \mathrm{~mm})$.

Maurer et al demonstrated the feasibility of a PSMA-labelled radiotracer $\left({ }^{111}\right.$ In-PSMAI\&T) for SLND in their series of 5 patients [54]. Intra-operative gamma probe detection was fed into an augmented reality display to provide a reconstructed 3D image identifying hotspots in an open operating field. They detected $2-4 \mathrm{~mm}$ lesions and additional nodes not detected on ${ }^{68} \mathrm{Ga}-\mathrm{PSMA} \mathrm{PET}$.

Recently, feasibility studies have established the stability of different SPIO Nanoparticlebound PSMA ligands, including smaller antibody fragments and polypeptides [44,55]. In a murine model, PSMA-targeting polypeptides increased the uptake of SPIO Nanoparticles by a PCa cell line that expressed PMSA (LnCaP). Moreover, in vivo MRI 
showed significant T2 signal changes post-polypeptide injection compared to control, supporting evidence that targeting PSMA could offer specific PCa enhancement [44]. An advantage of this approach is the ability to administer intravenous doses of the tracer, hence overriding the issues surrounding compromised lymph flow or rerouting. The use of ${ }^{68} \mathrm{Ga}$-PSMA PET/ CT as gold standard for staging is precluded by its moderate sensitivity, as confirmed by prospective study of intermediate- and high-risk PCa patients [56]. Per patient, side, region and node, ${ }^{68} \mathrm{Ga}-\mathrm{PSMA} \mathrm{PET} / \mathrm{CT}$ had a specificity of $95 \%, 98 \%, 99 \%, 100 \%$, but a sensitivity of only $64 \%, 56 \% 54 \%$ and $58 \%$, respectively. Eiber et al's[57] report on the diagnostic performance of ${ }^{68} \mathrm{Ga}-\mathrm{PSMA}, \mathrm{PET}$ and multiparametric MRI (mpMRI) may however start a paradigm shift. 53 patients with similar risk profile underwent ${ }^{68} \mathrm{Ga}$-PSMA PET/MRI to localise primary PCa prior to elective RP. The imaging combination demonstrated markedly improved sensitivity compared to mpMRI alone; $98 \%$ vs $66 \%(p<0.001)$, while no significant difference was found compared to PET alone.

These promising results highlight the need for a well-designed feasibility study to characterise the diagnostic value of mpMRI combined with PET, ${ }^{68} \mathrm{Ga}$-PSMA and SPIObased agents. 


\section{CONCLUSION}

The main downfall of the SLND concept in PCa has been its inability to identify a constant SLN or packet of SLNs for the prostate. Despite the internal iliac nodes purporting to fulfil this role, it is evident from anatomical studies that the lymphatic pathways of the prostate are more complex than previously assumed. The current tracer modalities that only delineate the general lymphatic drainage of the gland transform the procedure into a broad radio- or fluorescence-guided dissection. As such, most SLND patients still undergo a backup PLND and there is a paucity of evidence surrounding the follow-up of those who only receive SLND. Given the unpredictable changes of lymphovascular flow secondary to tumour invasion or prior intervention the future of a true SLND seems to lie with intravenous PCa-targeted ligands bound to an intraoperatively-detectable tracer. 
Conflicts of interest: The authors have no conflict of interest to disclose.

Funding: This research did not receive any specific grant from funding agencies in the public, commercial, or not-for-profit sectors. 


\section{REFERENCES}

[1] Briganti A, Larcher A, Abdollah F, Capitanio U, Gallina A, Suardi N, et al. Updated nomogram predicting lymph node invasion in patients with prostate cancer undergoing extended pelvic lymph node dissection: The essential importance of percentage of positive cores. Eur Urol 2012;61:480-7. doi:10.1016/j.eururo.2011.10.044.

[2] Heidenreich A, Bastian PJ, Bellmunt J, Bolla M, Joniau S, Van Der Kwast T, et al. EAU guidelines on prostate cancer. Part 1: Screening, diagnosis, and local treatment with curative intent - Update 2013. vol. 65. 2014. doi:10.1016/j.eururo.2013.09.046.

[3] Fajkovic H, D M, Mathieu R, D M, Lucca I, D M, et al. Validation of lymphovascular invasion is an independent prognostic factor for biochemical recurrence after radical prostatectomy. Urol Oncol Semin Orig Investig 2016;34:1-6. doi:10.1016/j.urolonc.2015.10.013.

[4] Ponholzer A, Lamche M, Klitsch M, Kraischits N, Hiess M, Schenner M, et al. Sentinel lymphadenectomy compared to extended lymphadenectomy in men with prostate cancer undergoing prostatectomy. Anticancer Res 2012;32:1033-6.

[5] Bivalacqua TJ, Pierorazio PM, Gorin MA, Allaf ME, Carter HB, Walsh PC. Anatomic extent of pelvic lymph node dissection: Impact on long-term cancer-specific outcomes in men with positive lymph nodes at time of radical prostatectomy. Urology 2013;82:653-9. doi:10.1016/j.urology.2013.03.086.

[6] KleinJan GH, van den Berg NS, de Jong J, Wit EM, Thygessen H, Vegt E, et al. Multimodal hybrid imaging agents for sentinel node mapping as a means to (re)connect nuclear medicine to advances made in robot-assisted surgery. Eur J Nucl Med Mol Imaging 2016. doi:10.1007/s00259-015-3292-2.

[7] Kleinjan GH, Van Den Berg NS, Brouwer OR, De Jong J, Acar C, Wit EM, et al. Optimisation of fluorescence guidance during robot-assisted laparoscopic sentinel node biopsy for prostate cancer. Eur Urol 2014;66:991-8. doi:10.1016/j.eururo.2014.07.014.

[8] Vermeeren L, Valdés Olmos R a, Meinhardt W, Bex A, van der Poel HG, Vogel W V, et al. 
Value of SPECT/CT for detection and anatomic localization of sentinel lymph nodes before laparoscopic sentinel node lymphadenectomy in prostate carcinoma. J Nucl Med 2009;50:865-70. doi:10.2967/jnumed.108.060673.

[9] Van Der Poel HG, Buckle T, Brouwer OR, Valdés Olmos RA, Van Leeuwen FWB. Intraoperative laparoscopic fluorescence guidance to the sentinel lymph node in prostate cancer patients: Clinical proof of concept of an integrated functional imaging approach using a multimodal tracer. Eur Urol 2011;60:826-33. doi:10.1016/j.eururo.2011.03.024.

[10] Holl G, Dorn R, Wengenmair H, Weckermann D, Sciuk J. Validation of sentinel lymph node dissection in prostate cancer: Experience in more than 2,000 patients. Eur J Nucl Med Mol Imaging 2009;36:1377-82. doi:10.1007/s00259-009-1157-2.

[11] Schilling D, Boekeler U, Gakis G, Schwentner C, Corvin S, Sotlar K, et al. Modified concept for radioisotope-guided sentinel lymph node dissection in prostate cancer. World $\mathrm{J}$ Urol 2010;28:715-20. doi:10.1007/s00345-010-0533-7.

[12] Winter A, Kneib T, Henke R, Wawroschek F. Sentinel lymph node dissection in more than 1200 prostate cancer cases: rate and prediction of lymph node involvement depending on preoperative tumor characteristics. Int J Urol 2014;21:58-63. doi:10.1111/iju.12184.

[13] Bastide C, Brenot-Rossi I, Garcia S, Rossi D. Radioisotope guided sentinel lymph node dissection in patients with localized prostate cancer: results of the first 100 cases. Eur $\mathrm{J}$ Surg Oncol 2009;35:751-6. doi:10.1016/j.ejso.2008.04.007.

[14] Rousseau C, Rousseau T, Campion L, Lacoste J, Aillet G, Potiron E, et al. Laparoscopic Sentinel Lymph Node Versus Hyperextensive Pelvic Dissection for Staging Clinically Localized Prostate Carcinoma: A Prospective Study of 200 Patients. J Nucl Med 2014;55:753-8. doi:10.2967/jnumed.113.129023.

[15] Acar C, Kleinjan GH, van den Berg NS, Wit EM, van Leeuwen FW, van der Poel HG. Advances in sentinel node dissection in prostate cancer from a technical perspective. Int $\mathrm{J}$ Urol 2015;22:898-909. doi:10.1111/iju.12863. 
[16] Egawa M, Fukuda M, Takashima H, Misaki T, Kinuya K, Terahata S. The sentinel node concept in prostate cancer: Present reality and future prospects. Indian J Urol 2008;24:4516. doi:10.4103/0970-1591.44246.

[17] Kiss B, Thoeny HC, Studer UE. Current Status of Lymph Node Imaging in Bladder and Prostate Cancer. Urology 2016:1-7. doi:10.1016/j.urology.2016.02.014.

[18] Jakobsen JK. Sentinel node biopsy in uro-oncology: A history of the development of a promising concept. Urol Oncol Semin Orig Investig 2015;33:486-93. doi:10.1016/j.urolonc.2015.08.010.

[19] Cabanas RM. An approach for the treatment of penile carcinoma. Cancer 1977;39:456-66.

[20] Wawroschek F, Vogt H, Weckermann D, Wagner T, Harzmann R. The sentinel lymph node concept in prostate cancer - First results of gamma probe-guided sentinel lymph node identification. Eur Urol 1999;36:595-600. doi:10.1159/000020054.

[21] Pillai MR a, Knapp FFR. Overcoming the $99 \mathrm{mTc}$ shortage: are options being overlooked? J Nucl Med 2011;52:15N - 16N, 28N. doi:52/2/15N [pii].

[22] Stoffels I, Dissemond J, Pöppel T, Schadendorf D, Klode J. Intraoperative Fluorescence Imaging for Sentinel Lymph Node Detection Prospective Clinical Trial to Compare the Usefulness of Indocyanine Green vs Technetium Tc 99m for Identification of Sentinel Lymph Nodes 2015. doi:10.1001/jamasurg.2014.3502.

[23] Inoue S, Shiina H, Arichi N, Mitsui Y, Hiraoka T, Wake K, et al. Identification of lymphatic pathway involved in the spreading of prostate cancer by fluorescence navigation approach with intraoperatively injected indocyanine green. J Can Urol Assoc 2011. doi:10.5489/cuaj.10159.

[24] Winter A, Woenkhaus J, Wawroschek F. A novel method for intraoperative sentinel lymph node detection in prostate cancer patients using superparamagnetic iron oxide nanoparticles and a handheld magnetometer: the initial clinical experience. Ann Surg Oncol 2014;21:4390-6. doi:10.1245/s10434-014-4024-8. 
[25] Rosenthal EL, Warram JM, Bland KI, Zinn KR. The status of contemporary image-guided modalities in oncologic surgery. Ann Surg 2015;261:46-55. doi:10.1097/SLA.0000000000000622.

[26] Hruby S, Englberger C, Lusuardi L, Schätz T, Kunit T, Abdel-Aal AM, et al. Fluorescence Guided Targeted Pelvic Lymph Node Dissection for Intermediate and High Risk Prostate Cancer. J Urol 2015;194:357-63. doi:10.1016/j.juro.2015.03.127.

[27] Liss MA, Stroup SP, Qin Z, Hoh CK, Hall DJ, Vera DR, et al. Robotic-assisted fluorescence sentinel lymph node mapping using multimodal image guidance in an animal model. Urology 2014;84:982.e9-982.e14. doi:10.1016/j.urology.2014.06.021.

[28] Manny TB, Patel M, Hemal AK. Fluorescence-enhanced robotic radical prostatectomy using real-time lymphangiography and tissue marking with percutaneous injection of unconjugated indocyanine green: The initial clinical experience in 50 patients. Eur Urol 2014;65:1162-8. doi:10.1016/j.eururo.2013.11.017.

[29] Yuen K, Miura T, Sakai I, Kiyosue A, Yamashita M. Intraoperative Fluorescence Imaging for Detection of Sentinel Lymph Nodes and Lymphatic Vessels during Open Prostatectomy using Indocyanine Green. J Urol 2015;194:371-7. doi:10.1016/j.juro.2015.01.008.

[30] Nguyen DP, Huber PM, Metzger TA, Genitsch V, Schudel HH, Thalmann GN. A Specific Mapping Study Using Fluorescence Sentinel Lymph Node Detection in Patients with Intermediate- and High-risk Prostate Cancer Undergoing Extended Pelvic Lymph Node Dissection. Eur Urol 2016:10-3. doi:10.1016/j.eururo.2016.01.034.

[31] Jeschke S, Lusuardi L, Myatt A, Hruby S, Pirich C, Janetschek G. Visualisation of the lymph node pathway in real time by laparoscopic radioisotope- and fluorescence-guided sentinel lymph node dissection in prostate cancer staging. Urology 2012;80:1080-7. doi:10.1016/j.urology.2012.05.050.

[32] Brouwer O, Buckle T, Vermeeren L, Klop W, Balm A, Van Der Poel HG, et al. Comparing the hybrid fluorescent-radioactive tracer indocyanine green-99mTc-Nanocolloid with99mTc- 
nanocolloid for sentinel node identification: A validation study using lymphoscintigraphy and SPECT/CT. J Nucl Med 2012;53:1034-40. doi:10.2967/jnumed.112.103127.

[33] van den Berg NS, Miwa M, KleinJan GH, Sato T, Maeda Y, van Akkooi ACJ, et al. (NearInfrared) Fluorescence-Guided Surgery Under Ambient Light Conditions: A Next Step to Embedment of the Technology in Clinical Routine. Ann Surg Oncol 2016:1-10. doi:10.1245/s10434-016-5186-3.

[34] Joniau S, Van Den Bergh L, Lerut E, Deroose CM, Haustermans K, Oyen R, et al. Mapping of pelvic lymph node metastases in prostate cancer. Eur Urol 2013;63:450-8. doi:10.1016/j.eururo.2012.06.057.

[35] Buckle T, Brouwer OR, Valdes Olmos RA, van der Poel HG, van Leeuwen FWB. Relationship Between Intraprostatic Tracer Deposits and Sentinel Lymph Node Mapping in Prostate Cancer Patients. J Nucl Med 2012;53:1026-33. doi:10.2967/jnumed.111.098517.

[36] Mattei A, Fuechsel FG, Bhatta Dhar N, Warncke SH, Thalmann GN, Krause T, et al. The Template of the Primary Lymphatic Landing Sites of the Prostate Should Be Revisited: Results of a Multimodality Mapping Study. Eur Urol 2008;53:118-25. doi:10.1016/j.eururo.2007.07.035.

[37] Ganswindt U, Schilling D, Müller AC, Bares R, Bartenstein P, Belka C. Distribution of prostate sentinel nodes: A SPECT-derived anatomic atlas. Int J Radiat Oncol Biol Phys 2011;79:1364-72. doi:10.1016/j.jprobp.2010.01.012.

[38] Staník M, Čapák I, Macík D, Vašina J, Lžičařová E, Jarkovský J, et al. Sentinel lymph node dissection combined with meticulous histology increases the detection rate of nodal metastases in prostate cancer. Int Urol Nephrol 2014;46:1543-9. doi:10.1007/s11255-0140704-3.

[39] Fukuda M, Egawa M, Imao T, Takashima H, Yokoyama K, Namiki M. Detection of Sentinel Node Micrometastasis by Step Section and Immunohistochemistry in Patients With Prostate Cancer. J Urol 2007;177:1313-7. doi:10.1016/j.juro.2006.11.085. 
[40] Häcker A, Jeschke S, Leeb K, Prammer K, Ziegerhofer J, Sega W, et al. Detection of pelvic lymph node metastases in patients with clinically localized prostate cancer: comparison of [18F]fluorocholine positron emission tomography-computerized tomography and laparoscopic radioisotope guided sentinel lymph node dissection. J Urol 2006;176:2014-8; discussion 2018-9. doi:10.1016/j.juro.2006.07.037.

[41] Jeschke S, Beri A, Grüll M, Ziegerhofer J, Prammer P, Leeb K, et al. Laparoscopic Radioisotope-Guided Sentinel Lymph Node Dissection in Staging of Prostate Cancer. Eur Urol 2008;53:126-33. doi:10.1016/j.eururo.2007.03.064.

[42] Weckermann D, Holl G, Dorn R, Wagner T, Harzmann R. Reliability of preoperative diagnostics and location of lymph node metastases in presumed unilateral prostate cancer. BJU Int 2007;99:1036-40. doi:10.1111/j.1464-410X.2007.06791.x.

[43] Warncke SH, Mattei A, Fuechsel FG, Z'Brun S, Krause T, Studer UE, et al. Detection Rate and Operating Time Required for y Probe-Guided Sentinel Lymph Node Resection after Injection of Technetium-99m Nanocolloid into the Prostate with and without Preoperative Imaging. Eur Urol 2007;52:126-33. doi:10.1016/j.eururo.2007.01.050.

[44] Zhu Y, Sun Y, Chen Y, Liu W, Jiang J, Guan W, et al. In Vivo Molecular MRI Imaging of Prostate Cancer by Targeting PSMA with Polypeptide-Labeled Superparamagnetic Iron Oxide Nanoparticles. Int J Mol Sci 2015;16:9573-87. doi:10.3390/ijms16059573.

[45] Harisinghani MG, Barentsz J, Hahn PF, Deserno WM, Tabatabaei S, Hulsbergen van de Kaa C, et al. Noninvasive Detection of Clinically Occult Lymph-Node Metastases in Prostate Cancer. N Engl J Med 2003;34825348:2491-9.

[46] Vermeeren L, Meinhardt W, Van Der Poel HG, Valdés Olmos RA. Lymphatic drainage from the treated versus untreated prostate: Feasibility of sentinel node biopsy in recurrent cancer. Eur J Nucl Med Mol Imaging 2010;37:2021-6. doi:10.1007/s00259-010-1527-9.

[47] Muck A, Langesberg C, Mugler M, Rahnenführer J, Wullich B, Schafhauser W. Clinical Outcome of Patients with Lymph Node-Positive Prostate Cancer following Radical 
Prostatectomy and Extended Sentinel Lymph Node Dissection. Urol Int 2014;94:296-306. doi:10.1159/000365011.

[48] Lütje S, Heskamp S, Cornelissen AS, Poeppel TD, M W van den Broek SA, RosenbaumKrumme S, et al. PSMA Ligands for Radionuclide Imaging and Therapy of Prostate Cancer: Clinical Status. Theranostics 2015;5:1388-401. doi:10.7150/thno.13348.

[49] Rowe S, Gorin M, Allaf M, Pienta K, Tran P, Pomper M, et al. PET imaging of prostatespecific membrane antigen in prostate cancer: current state of the art and future challenges. Prostate Cancer Prostatic Dis Adv Online Publ 2016. doi:10.1038/pcan.2016.13.

[50] Sankineni S, Brown AM, Fascelli M, Law YM, Pinto PA, Choyke PL, et al. Lymph Node Staging in Prostate Cancer. Curr Urol Rep 2015;16:1-9. doi:10.1007/s11934-015-0505-y.

[51] Wright GL, Haley C, Beckett M Lou, Schellhammer PF. Expression of prostate-specific membrane antigen in normal, benign, and malignant prostate tissues. Urol Oncol Semin Orig Investig 1995;1:18-28. doi:10.1016/1078-1439(95)00002-Y.

[52] Afshar-Oromieh A, Zechmann CM, Malcher A, Eder M, Eisenhut M, Linhart HG, et al. Comparison of PET imaging with a 68Ga-labelled PSMA ligand and 18F-choline-based $\mathrm{PET} / \mathrm{CT}$ for the diagnosis of recurrent prostate cancer. Eur $\mathrm{J}$ Nucl Med Mol Imaging 2014;41:11-20. doi:10.1007/s00259-013-2525-5.

[53] Budäus L, Leyh-Bannurah S-R, Salomon G, Michl U, Heinzer H, Huland H, et al. Initial Experience of 68Ga-PSMA PET/CT Imaging in High-risk Prostate Cancer Patients Prior to Radical Prostatectomy. vol. 69. 2016. doi:10.1016/j.eururo.2015.06.010.

[54] Maurer T, Weirich G, Schottelius M, Weineisen M, Frisch B, Okur A, et al. Prostate-specific Membrane Antigen-radioguided Surgery for Metastatic Lymph Nodes in Prostate Cancer. vol. 68. 2015. doi:10.1016/j.eururo.2015.04.034.

[55] Bates D, Abraham S, Campbell M, Zehbe I, Curiel L, Furlan R. Development and Characterization of an Antibody- Labeled Super-Paramagnetic Iron Oxide Contrast Agent Targeting Prostate Cancer Cells for Magnetic Resonance Imaging. PLoS One 2014;9. 
doi:10.1371/journal.pone.0097220.

[56] van Leeuwen PJ, Emmett L, Ho B, Delprado W, Ting F, Nguyen Q, et al. Prospective Evaluation of 68Gallium-PSMA Positron Emission Tomography/Computerized Tomography for Preoperative Lymph Node Staging in Prostate Cancer. BJU Int 2016. doi:10.1111/bju.13540.

[57] Eiber M, Weirich G, Holzapfel K, Souvatzoglou M, Haller B, Rauscher I, et al. Simultaneous (68)Ga-PSMA HBED-CC PET/MRI Improves the Localization of Primary Prostate Cancer. Eur Urol 2016:6-13. doi:10.1016/j.eururo.2015.12.053. 
ACCEPTED MANUSCRIPT

\begin{tabular}{|c|c|c|c|c|c|c|c|c|c|c|c|c|c|c|c|c|}
\hline \multirow{2}{*}{ Study } & \multicolumn{16}{|c|}{$\begin{array}{l}\text { Anatomical distribution rates of intraoperatively detected SLN (\%) } \\
\text { [Preoperative SLN detection if reported] }\end{array}$} \\
\hline & OF & $\mathrm{El}$ & II & $\mathrm{Cl}$ & PS & PR & PA & PV & UL & MF & $A B$ & PP & $\mathrm{IR}$ & IB & FoM & ${ }^{*}$ US \\
\hline $\begin{array}{l}\text { Bastide et al } \\
2009[13]\end{array}$ & 30.4 & 11.6 & 53.9 & 3.8 & - & - & - & 0.3 & - & - & - & - & - & - & - & - \\
\hline $\begin{array}{l}\text { Schillling et al } \\
2010[11]\end{array}$ & $\begin{array}{c}41.2 \\
{[23.3]}\end{array}$ & 19.9 & 33.9 & 3.9 & 1.0 & - & 0.1 & - & - & - & - & - & - & - & - & $\begin{array}{c}\mathrm{NR} \\
{[76.7]}\end{array}$ \\
\hline $\begin{array}{l}\text { Jeschke et al } \\
2012 \text { [31] }\end{array}$ & 24.0 & 34.7 & 19.9 & 3.3 & 6.6 & - & 2.6 & - & 6.3 & - & - & & - & 2.6 & - & - \\
\hline $\begin{array}{l}\text { Joniau et al } \\
2013[34]\end{array}$ & $\begin{array}{c}25.3 \\
{[16.6]}\end{array}$ & $\begin{array}{c}19.1 \\
{[16.4]}\end{array}$ & $\begin{array}{c}24.5 \\
{[22.8]}\end{array}$ & $\begin{array}{c}14.3 \\
{[18.7]}\end{array}$ & $\begin{array}{l}13.2 \\
{[7.4]}\end{array}$ & $\begin{array}{c}1.6 \\
{[3.0]}\end{array}$ & $\begin{array}{c}0.8 \\
{[10.4]}\end{array}$ & $\begin{array}{c}0.3 \\
{[0.4]}\end{array}$ & - & $\begin{array}{c}0.5 \\
{[0.4]}\end{array}$ & $\begin{array}{l}0.3 \\
{[3.6]}\end{array}$ & - & - & - & - & - \\
\hline $\begin{array}{l}\text { Rousseau et } \\
\text { al } 2014[14]\end{array}$ & $\begin{array}{c}27.0 \\
{[17.7]}\end{array}$ & $\begin{array}{c}25.2 \\
{[15.1]}\end{array}$ & $\begin{array}{c}26.1 \\
{[19.8]}\end{array}$ & $\begin{array}{c}19.5 \\
{[31.1]}\end{array}$ & $\begin{array}{c}2.2 \\
{[6.3]}\end{array}$ & 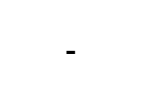 & - & & & & & - & - & - & - & $\begin{array}{l}N R \\
{[10]}\end{array}$ \\
\hline $\begin{array}{l}\text { Kleinjan et al } \\
2014 \text { [7] }\end{array}$ & 37.0 & 26.8 & 12.6 & 9.4 & 3.9 & 3.9 & 1.6 & 3.1 & 1.6 & & - & - & - & - & - & - \\
\hline $\begin{array}{l}\text { Manny et al } \\
2014[28]\end{array}$ & 53.0 & 42.0 & 11.0 & 8.0 & - & - & 5.0 & - & & & - & 13.0 & - & - & - & - \\
\hline $\begin{array}{l}\text { Staník et al } \\
2014[38]\end{array}$ & 28.4 & 26.9 & 28.1 & 7.2 & 5.7 & 1.8 & 1.5 & - & & & - & - & 0.6 & - & - & - \\
\hline $\begin{array}{l}\text { Hruby et al } \\
2015[26]\end{array}$ & 39.5 & 30.5 & 12.4 & 4.9 & 7.3 & - & 0.2 & - & 5.2 & - & - & - & - & - & - & - \\
\hline $\begin{array}{l}\text { Yuen et al } \\
2015[29]\end{array}$ & 53.4 & 16.1 & 28.3 & 1.6 & 0.6 & - & - & & 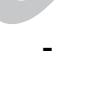 & - & - & - & - & - & - & - \\
\hline $\begin{array}{l}\text { Kleinjan et al } \\
2016[6]\end{array}$ & 28.3 & 27.2 & 23.4 & 6.0 & 6.5 & 4.9 & 0.5 & & - & - & - & - & - & - & - & 3.3 \\
\hline $\begin{array}{l}\text { Nguyen et al } \\
2016[30]\end{array}$ & NR & 47.9 & 23.5 & 16.3 & - & - & & - & - & - & - & - & - & - & 12.3 & - \\
\hline & OF & $\mathrm{EI}$ & $\|$ & $\mathrm{Cl}$ & PS & PR & PA & PV & UL & MF & $A B$ & $\mathrm{PP}$ & $\mathrm{IR}$ & IB & FoM & \\
\hline Mean (\%) & $\begin{array}{c}35 \\
{[24]}\end{array}$ & $\begin{array}{c}27 \\
{[19]}\end{array}$ & $\begin{array}{c}25 \\
{[18]}\end{array}$ & $\begin{array}{c}8 \\
{[20]}\end{array}$ & $\begin{array}{c}5 \\
{[6]}\end{array}$ & & $\begin{array}{c}2 \\
{[6]}\end{array}$ & $\begin{array}{l}1.2 \\
{[2]}\end{array}$ & $\begin{array}{c}4 \\
{[1.6]}\end{array}$ & $\begin{array}{c}0.5 \\
{[0.4]^{\wedge}}\end{array}$ & $\begin{array}{c}0.3 \\
{[3.6]^{\wedge}}\end{array}$ & $\begin{array}{c}13 \\
{[-]^{\wedge}}\end{array}$ & $\begin{array}{c}0.6 \\
{[0.2]^{\wedge}}\end{array}$ & $\begin{array}{l}2.6 \\
{[-]^{\wedge}}\end{array}$ & $\begin{array}{l}12.3 \\
{[-]^{\wedge}}\end{array}$ & \\
\hline Median (\%) & $\begin{array}{c}30 \\
{[21]}\end{array}$ & $\begin{array}{c}27 \\
{[16]}\end{array}$ & $\begin{array}{c}24 \\
{[20]}\end{array}$ & $\begin{array}{c}7 \\
{[19]}\end{array}$ & & 3 & $\begin{array}{l}1.2 \\
{[6]}\end{array}$ & $\begin{array}{l}0.3 \\
{[2]}\end{array}$ & $\begin{array}{c}5 \\
{[1.6]}\end{array}$ & $\begin{array}{c}0.5 \\
{[0.4]^{\wedge}}\end{array}$ & $\begin{array}{c}0.3 \\
{[3.6]^{\wedge}}\end{array}$ & $\begin{array}{c}13 \\
{[-]^{\wedge}}\end{array}$ & $\begin{array}{c}0.6 \\
{[0.2]^{\wedge}}\end{array}$ & $\begin{array}{l}2.6 \\
{[-]^{11}}\end{array}$ & $\begin{array}{l}12.3 \\
{[-]^{\wedge}}\end{array}$ & \\
\hline Range (\%) & $\begin{array}{c}24-53 \\
{[17-37]}\end{array}$ & $\begin{array}{c}12-48 \\
{[15-27]}\end{array}$ & $\begin{array}{c}11-54 \\
{[13-23]}\end{array}$ & $\begin{array}{c}2-20 \\
{[9-31]}\end{array}$ & $\begin{array}{l}0.6-13 \\
{[4-7]}\end{array}$ & $\begin{array}{c}2-5 \\
{[3.0-3.9]}\end{array}$ & $\begin{array}{c}0.1-5 \\
{[2-10]}\end{array}$ & $\begin{array}{l}0.3-3 \\
{[0.4-3]}\end{array}$ & $\begin{array}{l}2-6 \\
{[1.6]}\end{array}$ & $\begin{array}{c}0.5 \\
{[0.4]^{\wedge}}\end{array}$ & $\begin{array}{c}0.3 \\
{[3.6]^{\wedge}}\end{array}$ & $\begin{array}{l}13 \\
{[-]^{\wedge}}\end{array}$ & $\begin{array}{c}0.6 \\
{[0.2]^{\wedge}}\end{array}$ & $\begin{array}{l}2.6 \\
{[-]^{\wedge}}\end{array}$ & $\begin{array}{l}12.3 \\
{[-]^{\wedge}}\end{array}$ & \\
\hline
\end{tabular}

Table 1. Anatomical distribution rates of sentinel lymph nodes detected pre-operatively ( $\mathrm{n}=3$ studies) and intraoperatively ( $\mathrm{n}=12$ studies). 
Obturator fossa, OF; External iliac, El; Internal iliac, II; Common iliac, CI; Paraaortic, PA; Aortic bifurcation, AB; Iliac bifurcation, IB; Presacral, PS; Pararectal, PR; Paravesical, PV; Mesenteric fat, MF; Umbilical ligament, UL; Preprostatic, PP; Inguinal region, IR; Fossa of Marcille, FoM; Unspecified, US; Not Reported, NR

^reported in one study only. 


\begin{tabular}{|c|ccc|}
\hline \multirow{2}{*}{ Bilateral dissection extent } & \multicolumn{3}{|c|}{ Proportion of cases with potentially missed nodal metastases } \\
& Median & Mean & Range \\
\hline Limited PLND (OF) & 74 & 70 & $50-88$ \\
Standard PLND (OF+El) & 42 & 45 & $25-71$ \\
Extended PLND (OF+El+II) & 10 & 11 & $0-24$ \\
Super-extended PLND & 3 & 4 & $0-13$ \\
(OF+El+II+Cl+PS) & & & \\
\hline
\end{tabular}

Table 2. Proportion of metastatic SLNs potentially missed by different dissection templates. Data extracted from 16 studies [4,7-11,13,14,26,28,29,34,38-41].

Obturator fossa, OF; External iliac, El; Internal iliac, II; Common iliac, Cl; Presacral, PS. 
ACCEPTED MANUSCRIPT

\begin{tabular}{|c|c|c|c|c|c|c|c|c|c|c|c|}
\hline \multirow[b]{2}{*}{ Study } & \multirow[b]{2}{*}{ Centre } & \multirow[b]{2}{*}{ Time } & \multirow[b]{2}{*}{ Size } & \multicolumn{5}{|c|}{$\begin{array}{l}\text { Population } \\
\end{array}$} & \multirow[b]{2}{*}{ Procedure } & \multirow[b]{2}{*}{ Tracer (Injection route) } & \multirow{2}{*}{$\begin{array}{l}\text { Imaging } \\
\text { i) Pre-operative } \\
\text { ii) Intra-operative }\end{array}$} \\
\hline & & & & $\begin{array}{c}\text { Median age } \\
\text { (range) }\end{array}$ & $\underset{(\text { Mg/ml) }}{\substack{\text { Mediange) } \\
\text { PSA (range }}}$ & \multicolumn{3}{|c|}{ Preoperative D'Amico Risk stratification } & & & \\
\hline Häcker et al 2006 [40] & Linz, Austria & $\begin{array}{l}\text { April 2004- November } \\
2005\end{array}$ & 20 & $\begin{array}{l}\text { Mean } 63.9 \\
(52-75)\end{array}$ & $27.1(9.2-100)$ & Low & Intermediate & NR & $\begin{array}{l}\text { Lap RP } \\
\text { (n=19; One cN2 patient) }\end{array}$ & $\begin{array}{l}{ }^{18} \text { F F Fluorocholine-IASOcholine } \Theta \\
\text { (Intravenous) } \\
200 \text { MBq } \\
\text { (Transrectal) }\end{array}$ & $\begin{array}{l}\text { i) }{ }^{18}{ }^{18} \mathrm{~F} \text { PETTCTT Lymphoscintigraphy } \\
\text { ii) Laparoscopic gamma probe }\end{array}$ \\
\hline $\begin{array}{l}\text { Warncke et al } 2007 \\
{[43]}\end{array}$ & Bern, Switzerland & NR & 36 & $\begin{array}{l}63 \\
(51-72)\end{array}$ & $\begin{array}{l}8 \\
(0.3-40)\end{array}$ & NR & NR & NR & Open RRP & 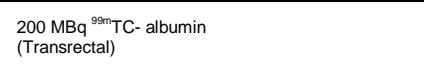 & $\begin{array}{l}\text { i) Lymphoscintigraphy, SPECT/CT or SPECT/MRI ( } n=1) \\
\text { ii) Handheld gamma probe }\end{array}$ \\
\hline Fukuda et al 2007 [39] & Kanazawa, Japan & Apr 2002- Mar 2004 & 42 & $\begin{array}{l}\text { Mean } 67.8 \\
(\mathrm{SD} \pm 5.8)\end{array}$ & $\begin{array}{l}\text { Mean } 25.1 \\
(\mathrm{SD} \pm 20.2)\end{array}$ & NR & NR & $226.2 \%$ & \begin{tabular}{|l|} 
Open staging \\
Iymphadenectomy
\end{tabular} & $\begin{array}{l}80 \text { MBq } 99 \mathrm{~m} T \mathrm{TC}-\text { phytate } \\
\text { (Transrectal) }\end{array}$ & $\begin{array}{l}\text { i) Lymphoscintigraphy, SPECT/CT } \\
\text { ii) Handheld gamma probe }\end{array}$ \\
\hline Jeschke et al 2008 [41] & Linz, Austria & Nov 2001- Jan 2005 & 140 & $\begin{array}{l}\text { Mean } 64.8 \\
(46-74)\end{array}$ & $\begin{array}{l}\text { Mean } 8.3 \\
(\mathrm{SD} \pm 9.5)\end{array}$ & $\begin{array}{l}73 \\
(52.1 \%) \\
\end{array}$ & $\begin{array}{l}50 \\
(35.7 \%)\end{array}$ & $\begin{array}{l}17 \\
(12.1 \%)\end{array}$ & \begin{tabular}{|l} 
LapRP \\
(n=139; One $\mathrm{CN} 1$ patient)
\end{tabular} & $\begin{array}{l}200 \mathrm{MBB}^{99 \mathrm{~m}} \mathrm{TC}-\text { albumin } \\
\text { (Transrectal) }\end{array}$ & $\begin{array}{l}\text { i) Lymphoscintigraphy } \\
\text { ii) Laparoscopic gamma probe }\end{array}$ \\
\hline $\begin{array}{l}\begin{array}{l}\text { Vermeeren et al } 2009 \\
\text { [8] }\end{array} \\
\end{array}$ & $\begin{array}{l}\text { Amsterdam, The } \\
\text { Netherlands }\end{array}$ & Jun 2006-Sep 2008 & 46 & $\begin{array}{l}65 \\
(53-74) \\
\end{array}$ & $\begin{array}{ll}15 \\
(2.1-208) \\
\end{array}$ & NR & NR & $282.6 \%$ & Radical Radiotherapy & 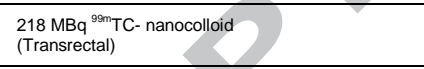 & $\begin{array}{l}\text { i) Lymphoscintigraphy, SPECT/CT } \\
\text { ii) Laparoscopic gamma probe, Portable mini gamma } \\
\text { camera }\end{array}$ \\
\hline Bastide et al 2009 [13] & Marseille, France & Mar 2003-Nov 2006 & 100 & $\begin{array}{l}63 \\
(43-77)\end{array}$ & $\begin{array}{l}10 \\
(1.2-70)\end{array}$ & $\begin{array}{l}54 \\
(54 \%)\end{array}$ & $\begin{array}{l}12 \\
(12 \%)\end{array}$ & $\begin{array}{l}34 \\
(34 \%)\end{array}$ & $\begin{array}{l}\text { Open RRP ( }(\mathrm{n}=87) \\
\text { Radical Radiotherapy (13) }\end{array}$ & $\begin{array}{l}\text { s9m } \mathrm{TC} \text { - nanocolloid } \\
\text { (Transrectal) } \\
\text { 1) } 60 \mathrm{MBq}(\mathrm{n}=72) \\
\text { 2) } 200 \mathrm{MBq}(\mathrm{n}=28) \\
\end{array}$ & $\begin{array}{l}\text { i) Lymphoscintigraphy } \\
\text { ii) Handheld gamma probe }\end{array}$ \\
\hline Holl et al 2009 [10] & Augsburg, Germany & Jul 1999-May 2008 & 2020 & $\begin{array}{r}\text { Mean 65.5 } \\
(43.2-80.4) \\
\end{array}$ & NR & NR & NR & NR & Open RRP & $\begin{array}{l}\text { 300MBq 9mic-nanocolloid } \\
\text { (Transrectal) }\end{array}$ & $\begin{array}{l}\text { i) Lymphoscintigraphy } \\
\text { ii) Handheld gamma probe }\end{array}$ \\
\hline Schilling et al 2010 [11] & Tuebingen, Germany & Oct 2002-Mar 2009 & 463 & $\begin{array}{l}64 \\
(44-79)\end{array}$ & $\begin{array}{l}\text { Mean } 11.6 \\
(0.1-289)\end{array}$ & NR & NR & NR & \begin{tabular}{|l|} 
Open RRP ( $\mathrm{n}=418)$ \\
$\begin{array}{l}\text { Laparoscopic staging PLND } \\
(\mathrm{n}=45)\end{array}$ \\
\end{tabular} & $\begin{array}{l}\text { 250MBg 9mm TC- nanocolloid } \\
\text { (Transrectal) }\end{array}$ & $\begin{array}{l}\text { i) SPECT/CT } \\
\text { ii) Handheld and Laparoscopic gamma probes }\end{array}$ \\
\hline $\begin{array}{l}\text { Inoue et al } \\
2011[23]\end{array}$ & Hiroshima, Japan & May 2007- Apr 2008 & 14 & $\begin{array}{l}68 \\
68-75)\end{array}$ & $\begin{array}{l}12.1 \\
(4.7-52.7)\end{array}$ & NR & NR & $257.1 \%$ & Open RRP & $\begin{array}{l}1 \mathrm{ml} \text { Free-ICG }(2.5 \mathrm{mg} / \mathrm{ml}) \\
\text { (Direct prostatic injection) }\end{array}$ & $\begin{array}{l}\text { i) - } \\
\text { ii) Handheld NIRF probe }\end{array}$ \\
\hline $\begin{array}{l}\text { Van der Poel et al } 2011 \\
\text { [9] }\end{array}$ & $\begin{array}{l}\text { Amsterdam, The } \\
\text { Netherlands }\end{array}$ & Jun 2010- Jan 2011 & 11 & $\begin{array}{l}63 \\
(50-74)\end{array}$ & $\begin{array}{l}12.2 \\
(4.3-27)\end{array}$ & - & $\begin{array}{l}5 \\
(45.5 \%)\end{array}$ & $\begin{array}{l}6 \\
(54.5 \%)\end{array}$ & RARP & $\begin{array}{l}\text { 280MBq Hybrid ICG-99mTC- nanocolloid } \\
\text { (Transrectal) }\end{array}$ & $\begin{array}{l}\text { i) Lymphoscintigraphy, SPECT/CT } \\
\text { ii) Laparoscopic gamma probe and NIRF imaging system }\end{array}$ \\
\hline $\begin{array}{l}\text { Ponholzer et al } 2012 \\
{[4]}\end{array}$ & Vienna, Austria & Feb 2008- Feb 2009 & 54 & $\begin{array}{l}\text { Mean 65.3 } \\
(50.9-75.6)\end{array}$ & $\begin{array}{l}\text { Mean 10.6 } \\
(2.8-66.5)\end{array}$ & - & $\begin{array}{l}36 \\
(66.6 \%)\end{array}$ & $\begin{array}{ll}18 \\
(33.4 \%) \\
\end{array}$ & \begin{tabular}{|l|} 
Open RRP $(n=38)$ \\
$\operatorname{LapRP}(n=16)$ \\
\end{tabular} & $\begin{array}{l}\begin{array}{l}240 \mathrm{MBB} \\
\text { (Transrectal) }\end{array} \\
\end{array}$ & $\begin{array}{l}\text { i) Lymphoscintigraphy, SPECT/CT } \\
\text { ii) Handheld and Laparoscopic gamma probes }\end{array}$ \\
\hline Jeschke et al $2012[31]$ & Salzburg, Austria & Mar 2010- Oct 2011 & 26 & $\begin{array}{l}62 \\
(49-74)\end{array}$ & $\begin{array}{l}12 \\
(2.9-52.8)\end{array}$ & - & $\begin{array}{l}20 \\
(76.9 \%)\end{array}$ & $\begin{array}{l}6 \\
(23.1 \%)\end{array}$ & LapRP & 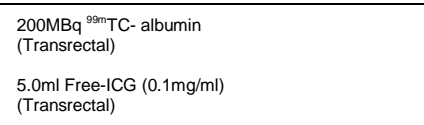 & $\begin{array}{l}\text { i) Lymphoscintigraphy, } \\
\text { ii) Laparoscopic ganma probe, Laparoscopic NIRF } \\
\text { imaging system }\end{array}$ \\
\hline Joniau et al 2013 [34] & Leuven, Belgium & Feb 2008- Feb 2011 & 74 & $\begin{array}{l}64.5 \\
(49.2-73.9)\end{array}$ & $\begin{array}{l}10.4 \\
(1.5-70.9)\end{array}$ & NR & NR & NA & RRP & 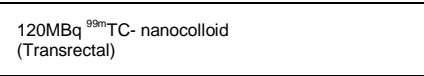 & $\begin{array}{l}\text { i) Lymphoscintigraphy, SPECT/CT } \\
\text { ii) Handheld gamma probe }\end{array}$ \\
\hline Manny et al 2014 [28] & Winston-Salem, USA & Oct 2012-Apr 2013 & 50 & $\begin{array}{l}\text { Mean } 66 \\
(51-73)\end{array}$ & $\begin{array}{l}6.5 \\
(1.9-32.9)\end{array}$ & $\begin{array}{l}15 \\
(30 \%)\end{array}$ & $\begin{array}{l}16 \\
(32 \%)\end{array}$ & $\begin{array}{l}19 \\
(38 \%)\end{array}$ & RARP & $\begin{array}{l}0.8 \mathrm{ml} \text { Free-ICG }(2.5 \mathrm{mg} / \mathrm{mll}) \\
\text { (Percutaneous robot-guided) }\end{array}$ & $\begin{array}{l}\text { i) - } \\
\text { ii) Integrated Firefly fluorescence laparoscope }\end{array}$ \\
\hline Winter et al 2014 [12] & Oldenburg, Germany & Jan 2005-Nov 2009 & 1229 & \begin{tabular}{|l|l|}
66 \\
$(41-78)$ \\
\end{tabular} & $\begin{array}{l}7.4 \\
(0.2-194) \\
\end{array}$ & $\begin{array}{ll}436 \\
(35.4 \%) \\
\end{array}$ & $\begin{array}{ll}446 \\
(36.2 \%) \\
\end{array}$ & $\begin{array}{ll}351 \\
(28.5 \%) \\
\end{array}$ & Open RRP & $\begin{array}{l}200 \mathrm{MBq} q^{99 m} \mathrm{TC}-\text { - nanocolloid } \\
\text { (Transrectal) }\end{array}$ & $\begin{array}{l}\text { i) Lymphoscintigraphy } \\
\text { ii) Handheld gamma probe }\end{array}$ \\
\hline $\begin{array}{l}\text { Rousseau et al } 2014 \\
{[14]}\end{array}$ & Saint Herblain, France & Jun 2008-Jul 2012 & 203 & \begin{tabular}{|l|l|}
64 \\
$(44-78)$ \\
\end{tabular} & $\begin{array}{l}8 \\
(2-130) \\
\end{array}$ & & $\begin{array}{l}163 \\
(80.3 \%) \\
\end{array}$ & $\begin{array}{l}40 \\
(19.7 \%)\end{array}$ & LapRP & $\begin{array}{l}249 \mathrm{MBq} \text { 99m TC-rhenium sulphide } \\
\text { (Transrectal) }\end{array}$ & $\begin{array}{l}\text { i) SPECT/CT } \\
\text { ii) Laparoscopic gamma probe }\end{array}$ \\
\hline Stanik et al 2014 [38] & Brno, Czech Republic & Oct 2010-Mar 2013 & 80 & \begin{tabular}{|l|}
63.5 \\
$(51-72)$
\end{tabular} & $\begin{array}{l}12.7 \\
(2.8-80.0)\end{array}$ & . & $\begin{array}{l}32 \\
(40 \%)\end{array}$ & $\begin{array}{l}48 \\
(60 \%)\end{array}$ & Open RRP & 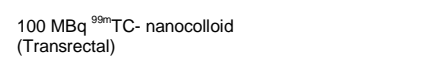 & $\begin{array}{l}\text { i) Lymphoscintigraphy, SPECT/CT } \\
\text { ii) Handheld gamma camera }\end{array}$ \\
\hline Kleinjan et at 2014 [7] & $\begin{array}{l}\text { Amsterdam, The } \\
\text { Netherlands }\end{array}$ & Dec 2010- Jul 2013 & 40 & \begin{tabular}{|l}
64 \\
$(60-68)$
\end{tabular} & & $\begin{array}{l}4 \\
(10 \%)\end{array}$ & $\begin{array}{l}30 \\
(75 \%)\end{array}$ & $\begin{array}{l}6 \\
(15 \%)\end{array}$ & RARP & $\begin{array}{l}\text { Hybrid IIGG-9minC- nanocolloid } \\
\text { (Transrectal) } \\
\text { 1) 280 MBg conventional hybrid formulation (n=11) } \\
\text { 2) Novel formulation (n } 13 \text { 1) } \\
\text { 3) Novel formulation and upgraded NIR imaging } \\
\text { system (n=16) }\end{array}$ & $\begin{array}{l}\text { i) Lymphoscintigraphy, 3D SPECT/CT } \\
\text { ii) Laparoscopic gamma probe, Laparoscopic NIRF } \\
\text { imaging system }\end{array}$ \\
\hline Winter et al 2014 [24] & Oldenburg, Germany & Dec 2013-Jan 2014 & 19 & $\begin{array}{l}65.5 \\
(53-78)\end{array}$ & $\begin{array}{l}12.6 \\
(1.3-50.5)\end{array}$ & $\cdot$ & $\begin{array}{l}13 \\
(65 \%)\end{array}$ & ${ }_{(35 \%)}^{7}$ & Open RRP & $\begin{array}{l}\text { SPIO nanoparticles (Sienna+9 } \\
\text { (Transrectal) }\end{array}$ & $\begin{array}{l}\text { i) - } \\
\text { ii) Handheld magnetometer (SentiMag" Probe) }\end{array}$ \\
\hline Hruby et al $2015[26]$ & Salzburg, Austria & Jan 2012- Sept 2013 & 38 & $\begin{array}{l}67.5 \\
(46-74)\end{array}$ & $\begin{array}{l}12.2 \\
(0.3-44)\end{array}$ & - & $\begin{array}{l}24 \\
(63 \%)\end{array}$ & $\begin{array}{l}14 \\
(37 \%)\end{array}$ & LapRP & $\begin{array}{l}\text { 5ml Free-ICG }(0.1 \mathrm{mg} / \mathrm{ml}) \\
\text { (Transperineal) }\end{array}$ & $\begin{array}{l}\text { i)- } \\
\text { ii) Laparoscopic NIRF imaging system }\end{array}$ \\
\hline
\end{tabular}


ACCEPTED MANUSCRIPT

\begin{tabular}{|c|c|c|c|c|c|c|c|c|c|c|c|}
\hline Yuen et al 2015 [29] & Kobe, Japan & Jan 2012- Jun 2014 & 66 & NR & NR & $9(14 \%)$ & $\begin{array}{l}25 \\
(23 \%)\end{array}$ & $\begin{array}{l}32 \\
(48 \%)\end{array}$ & Open RRP & $\begin{array}{l}2 \mathrm{ml} \text { Free-ICG } \\
\text { (Transrectal) } \\
(0.05 \mathrm{mg} / \mathrm{ml})\end{array}$ & 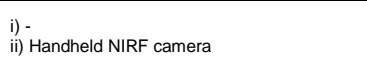 \\
\hline Kleinjan et al 2016 [6] & $\begin{array}{l}\text { Amsterdam, The } \\
\text { Netherlands }\end{array}$ & Jan 2014- Sept 2015 & 55 & $\begin{array}{l}63 \\
(59-68)\end{array}$ & $\begin{array}{l}7.9 \\
(5.46-12)\end{array}$ & $\begin{array}{l}21 \\
(38.2 \%)\end{array}$ & & $\begin{array}{l}34 \\
(61.8 \%)\end{array}$ & RARP & $\begin{array}{l}\text { Hybrid ICG-99m TC- nanocolloid [7] } \\
\text { (Transrectal) }\end{array}$ & $\begin{array}{l}\text { i) Lymphoscintigraphy, 3D SPECT/CT } \\
\text { ii) Integrated Firefly fluorescence laparoscope }\end{array}$ \\
\hline Nguyen et al 2016 [30] & Bern, Switzerland & Nov 2012- Sept 2015 & 42 & $\begin{array}{l}67 \\
(64-70)\end{array}$ & $\begin{array}{l}10.2 \\
(5.7-22.5)\end{array}$ & - & NR & NR & Open RRP & $\begin{array}{l}\text { Free-lCG (0.5mg/ml) } \\
\text { (Transrectal) } \\
\text { 1) } 6 \mathrm{ml} \text { sextant }(\mathrm{n}=12) \\
\text { 2) } 2 \mathrm{ml} \text { base/midportion or apex (n=18) } \\
\text { 3) } 3 \mathrm{ml} \text { right or left lobe }(\mathrm{n}=12) \\
\end{array}$ & 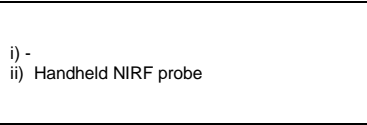 \\
\hline
\end{tabular}

Table 3. Characteristics of the studies reporting diagnostic performance of sentinel lymph node dissection at the time of radical surgery for prostate cancer.

Prostate carcinoma, PCa; Radical retropubic prostatectomy, RRP; Laparoscopic radical prostatectomy, LapRP; Robot-assisted radical prostatectomy, RARP; Superparamagnetic iron oxide, SPIO; Standard deviation, SD 
ACCEPTED MANUSCRIPT

\begin{tabular}{|c|c|c|c|c|c|c|c|c|c|c|c|c|c|c|c|c|}
\hline \multirow[b]{2}{*}{ Study } & \multirow[b]{2}{*}{ Gold standard } & \multicolumn{3}{|c|}{$\begin{array}{l}\text { Tumour His } \\
\text { Pathological Stage }\end{array}$} & \multicolumn{3}{|c|}{$\begin{array}{l}\text { pathology } \\
\text { Postoperative Gleason Score }\end{array}$} & \multirow[b]{2}{*}{ Pre-op SLN detection rate } & \multirow[b]{2}{*}{$\begin{array}{l}\text { Intra-op SLN detection } \\
\text { rate }\end{array}$} & \multirow{2}{*}{$\begin{array}{l}\text { Total SLN } \\
\text { detection } \\
\text { rate }\end{array}$} & \multirow{2}{*}{$\begin{array}{l}\text { Median } \\
\text { number } \\
\text { SLN } \\
\text { removed }\end{array}$} & \multirow{2}{*}{$\begin{array}{l}\text { Median } \\
\text { number of all } \\
\text { nodes } \\
\text { removed }\end{array}$} & \multirow[b]{2}{*}{ LNI (\%) } & \multirow{2}{*}{$\begin{array}{l}\text { Positive SLN } \\
\text { [Staging sensitivity] } \\
\text { ii) Per patient (\%)] } \\
\text { ii) Per positive node } \\
\text { (\%) }\end{array}$} & \multirow{2}{*}{$\begin{array}{l}\text { SLN FNR } \\
\text { ii) Per patient (\%) } \\
\text { ii) Per node (\%) }\end{array}$} & \multirow{2}{*}{$\begin{array}{l}\text { Micrometastatatic deposit } \\
\text { (\%) } \\
\text { i) Metastatic SLNs } \\
\text { ii) Metastatitic non-SLNS } \\
\text { iii) All metastatitic nodes }\end{array}$} \\
\hline & & $\begin{array}{l}\mathrm{T} 2 \\
(\%)\end{array}$ & $\begin{array}{l}\mathrm{T} 3 \\
(\%)\end{array}$ & T4 (\%) & $\leq 6(\%)$ & $7(\%)$ & $28(\%)$ & & & & & & & & & \\
\hline $\begin{array}{l}\text { Häcker et al } 2006 \\
{[40]}\end{array}$ & ePLND & $\begin{array}{l}7 \\
(38.9 \%)\end{array}$ & $\begin{array}{l}11 \\
(61.1 \%)\end{array}$ & - & $\begin{array}{l}7 \\
(38.9 \%)\end{array}$ & $\begin{array}{l}6 \\
(33.3 \%)\end{array}$ & $\begin{array}{l}5 \\
(27.8 \%)\end{array}$ & NR & $\begin{array}{l}\text { Sidewalls: } \\
\text { 32/38 (84.2\%) }\end{array}$ & 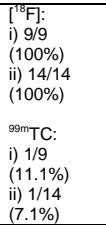 & NR & NR & $\begin{array}{l}\text { Mean } 14 \\
(\mathrm{SD} \pm 5.4)\end{array}$ & $\begin{array}{l}\text { All patients: } \\
\text { 10/20 (50\%) } \\
\text { Prostatectomy } \\
\text { patients: } \\
9 / 19 \text { (47.4\%) }\end{array}$ & 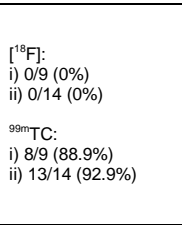 & NR \\
\hline $\begin{array}{l}\text { Warncke et al } \\
2007[43]\end{array}$ & ePLND & $\begin{array}{l}28 \\
(77.8 \%)\end{array}$ & $\begin{array}{l}7 \\
(19.4 \%)\end{array}$ & - & $\begin{array}{l}12 \\
(33.3 \%)\end{array}$ & $\begin{array}{l}22 \\
(61.1 \%)\end{array}$ & $\begin{array}{l}2 \\
(5.6 \%)\end{array}$ & $\begin{array}{l}36 / 36(100 \%) \\
100 \% \text { bilateral visualisation }\end{array}$ & $\begin{array}{l}\text { Without SPECT/CT/MRI } \\
\text { support (n=15): } \\
135 / 137(98.5 \%) \\
\text { With imaging support } \\
\text { (n=21): } \\
189 / 190(99.5 \%)\end{array}$ & $\begin{array}{l}\text { i) } 0 / 2(2 \%) \\
\text { ii) } 2 / 5 \% \\
(40 \%)\end{array}$ & $\begin{array}{l}327 / 327 \\
(100 \%)\end{array}$ & $\begin{array}{l}9 \\
\text { (Range 2-19) }\end{array}$ & $\begin{array}{l}15 \\
\text { (Range 6-35) }\end{array}$ & $2 / 36(5.6 \%)$ & $\begin{array}{l}\text { i) } 2 / 2(100 \%) \\
\text { ii) } 3 / 5(60 \%)\end{array}$ & NR \\
\hline $\begin{array}{l}\text { Fukuda et al } 2007 \\
{[39]}\end{array}$ & $\begin{array}{l}\text { ePLND + common } \\
\text { iliacs }\end{array}$ & - & - & - & - & - & - & $41 / 42(97.6 \%)$ & $42 / 42(100 \%)$ & 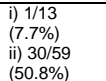 & $\begin{array}{l}42 / 42 \\
(100 \%)\end{array}$ & NR & $\begin{array}{l}\text { Mean 26.3 } \\
(\mathrm{SD} \pm 9.3)\end{array}$ & $13 / 42(31.0 \%)$ & $\begin{array}{l}\text { i) } 12 / 13(92.3 \%) \\
\text { ii) } 29 / 59(49.2 \%)\end{array}$ & $\begin{array}{l}\text { i) } N R \\
\text { ii) } N R \\
\text { iii) } 5 \text { micromets found }\end{array}$ \\
\hline $\begin{array}{l}\text { Jeschke et al } \\
2008[41]\end{array}$ & $\begin{array}{l}\text { LimPLND } \\
(n=71) \\
\text { ePLND } \\
(n=68) \\
\end{array}$ & $\begin{array}{l}89 \\
(64.0 \%)\end{array}$ & $\begin{array}{l}49 \\
(35.3 \%)\end{array}$ & $\begin{array}{l}1 \\
(0.7 \%)\end{array}$ & NR & NR & NR & $\begin{array}{l}133 / 139(95.3 \%) \\
81.3 \% \text { bilateral visualisation }\end{array}$ & 131/139 (94.2\%) & $\begin{array}{l}\text { i) } 11.19 \\
\text { (5.3\%) } \\
\text { iii. } 22.28 \\
(7.1 \%) \\
\end{array}$ & $\begin{array}{l}\begin{array}{l}133 / 139 \\
(95.3 \%)\end{array} \\
-\end{array}$ & $\begin{array}{l}4 \\
\text { (Range 1-20) }\end{array}$ & NR & 19/139 (13.7\%) & $\begin{array}{l}\text { i) } 18 / 19(94.7 \%) \\
\text { ii) } 26 / 28(92.9 \%)\end{array}$ & $\begin{array}{l}\text { i) } N R \\
\text { iii) NR } \\
\text { iii) } 10 \text { micromets found }\end{array}$ \\
\hline $\begin{array}{l}\text { Vermeeren et al } \\
2009[8]\end{array}$ & $\begin{array}{l}\text { ePLND + common } \\
\text { iliacs }\end{array}$ & $\begin{array}{l}6 \\
(13.0 \%)\end{array}$ & $\begin{array}{l}36 \\
(78.3 \%)\end{array}$ & $\begin{array}{l}2 \\
(4.3 \%)\end{array}$ & - & - & - & $\begin{array}{l}\text { Lymphoscinitigraphy: } \\
42 / 46 \text { (91.3\%) } \\
\text { SPECT/CT: } \\
45 / 466(97.8 \%) \\
\end{array}$ & NR & $\begin{array}{l}\text { i) } 0 / 15 \\
(0 \% \%) \\
\text { ii) } N R\end{array}$ & $\begin{array}{l}45 / 46 \\
(97.8 \%)\end{array}$ & & NR & $15 / 46(32.6 \%)$ & $\begin{array}{l}\text { i) } 15 / 15(100 \%) \\
\text { ii) } N R\end{array}$ & NR \\
\hline $\begin{array}{l}\text { Bastide et al } 2009 \\
{[13]}\end{array}$ & ePLND & $\begin{array}{l}52 \\
(59.8 \%)\end{array}$ & $\begin{array}{l}35 \\
(40.2 \%)\end{array}$ & & $\begin{array}{l}21 \\
(24.1 \%)\end{array}$ & $\begin{array}{l}55 \\
(63.2 \%)\end{array}$ & $\begin{array}{l}11 \\
(12.6 \%)\end{array}$ & $\begin{array}{l}87 / 100(87 \%) \\
76 \% \text { bilateral visualisation }\end{array}$ & $76 / 100(76 \%)$ & $\begin{array}{l}\text { i) } 2 / 12 \\
\text { (11.7\%) } \\
\text { ii) } 2213 \\
(15.4 \%)\end{array}$ & $\begin{array}{l}87 / 100 \\
(87 \%)\end{array}$ & $\begin{array}{l}3 \\
\text { (Range 1-13) }\end{array}$ & $\begin{array}{l}7 \\
\text { (Range 3-19) }\end{array}$ & $12 / 100(12 \%)$ & $\begin{array}{l}\text { i) } 10 / 12(83.3 \%) \\
\text { ii) } 11 / 13(84.6 \%)\end{array}$ & $\begin{array}{l}\text { i) } \mathrm{NR} \\
\text { ii) } \mathrm{NR} \\
\text { iii) } 5 / 12 \mathrm{pN}+\operatorname{cases}(41.7 \%)\end{array}$ \\
\hline $\begin{array}{l}\text { Holl et al } 2009 \\
{[10]}\end{array}$ & $\begin{array}{l}\text { SPLND (12\%) } \\
\text { ePLND }+ \text { + } \\
\text { common iliacs } \\
\text { (18\%) } \\
\text { Exclusive SLND } \\
(69 \%)\end{array}$ & NR & NR & $\mathrm{NR}$ & $\begin{array}{l}965 \\
(47.8 \%)\end{array}$ & $\begin{array}{l}863 \\
(42.7 \%)\end{array}$ & $\begin{array}{l}192 \\
(9.5 \%)\end{array}$ & 1971/2020 (97.6\%) & 1980/2020 (98.0\%) & $\begin{array}{l}\text { i) } 11 / 187 \\
(5.9 \%) \\
\text { ii) } 25 \% 469 \\
(5.3 \%)\end{array}$ & $\begin{array}{l}1984 / 2020 \\
(98.2 \%)\end{array}$ & $\begin{array}{l}\text { Mean 6.0 } \\
\text { (Total 12141) }\end{array}$ & $\begin{array}{l}\text { Mean 9.0 } \\
\text { (Total 18251) }\end{array}$ & $337 / 2020(16.7 \%)$ & $\begin{array}{l}\text { Patients with backup } \\
\text { PNLD (n=187) } \\
\text { i) } 176 / 187(94.1 \%) \\
\text { ii) } 444 / 469(94.6 \%)\end{array}$ & NR \\
\hline $\begin{array}{l}\text { Schilling et al } \\
2010[11]\end{array}$ & $\begin{array}{l}\begin{array}{l}\text { ePLND + common } \\
\text { iliacs }(n=418) \\
\text { LimPLND } \\
(n=45)\end{array} \\
(n=4)\end{array}$ & $\begin{array}{l}334 \\
(76.3 \%)\end{array}$ & $\begin{array}{l}104 \\
(23.7 \%)\end{array}$ & - & NR & NR & NR & $463 / 463(100 \%)$ & $413 / 463(89.2 \%)$ & $\begin{array}{l}\text { i) } 10 / 18 \\
\text { (3i. } \mathrm{N \%}) \\
\text { ii) } \mathrm{NR}\end{array}$ & $\begin{array}{l}463 / 463 \\
(100 \%)\end{array}$ & $\begin{array}{l}3 \\
\text { (Range 0-10) }\end{array}$ & $\begin{array}{l}13 \\
\text { (Range 2-48) }\end{array}$ & $28 / 463(6.0 \%)$ & $\begin{array}{l}\text { i) } 18 / 28(64.3 \%) \\
\text { ii) } N R\end{array}$ & NR \\
\hline $\begin{array}{l}\text { Inoue et al } \\
2011[23]\end{array}$ & ePLND & $\begin{array}{l}8 \\
(57.1 \%)\end{array}$ & $\begin{array}{l}6 \\
(42.9 \%)\end{array}$ & & ${ }_{(7.1 \%)}$ & $\begin{array}{l}8 \\
(57.1 \%)\end{array}$ & $\begin{array}{l}5 \\
(37.5 \%)\end{array}$ & & $\begin{array}{l}12 / 14 \\
(85.7 \%)\end{array}$ & $\begin{array}{l}\text { i) } 2 / 2 \\
\text { (100\%) } \\
\text { ii) } 202 \\
(100 \%) \\
\end{array}$ & $\begin{array}{l}12 / 14 \\
(85.7 \%)\end{array}$ & NR & $\begin{array}{l}\text { Mean 11.1 } \\
\text { (Range 1-12) }\end{array}$ & $2 / 14(14.3 \%)^{*}$ & $\begin{array}{l}\text { i) } 0 / 2(0 \%) \\
\text { ii) } 0 / 2(0 \%)\end{array}$ & NR \\
\hline $\begin{array}{l}\text { Van der Poel et al } \\
2011[9]\end{array}$ & ePLND & $\begin{array}{l}5 \\
(45.5 \%)\end{array}$ & $\begin{array}{l}5 \\
(45.5 \%)\end{array}$ & $(9.1 \%)$ & $\begin{array}{l}2 \\
(20 \%)\end{array}$ & $\begin{array}{l}5 \\
(50 \%)\end{array}$ & $\begin{array}{l}3 \\
(30 \%)\end{array}$ & 10/11 (90.9\%) & 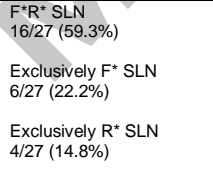 & $\begin{array}{l}\text { i) } 0 / 2(0 \%) \\
\text { ii) } 0 / 3(0 \%)\end{array}$ & $\begin{array}{l}10 / 11 \\
(90.9 \%) \\
\text { SLN } \\
\text { detected } \\
266 / 27 \\
(96.3 \%)\end{array}$ & (Range 0-4) & $\begin{array}{l}\text { Mean 10.2 } \\
\text { (Range 4-16) }\end{array}$ & 2/11 (18.2\%) & $\begin{array}{l}\text { i) } 2 / 2(100 \%) \\
\text { ii) } 3 / 3(100 \%)\end{array}$ & NR \\
\hline $\begin{array}{l}\begin{array}{l}\text { Ponholzer et al } \\
2012[4]\end{array} \\
\end{array}$ & ePLND & $\begin{array}{l}28 \\
(51.9 \%) \\
\end{array}$ & $\begin{array}{ll}26 \\
(48.1 \%) \\
\end{array}$ & - & $\begin{array}{l}15 \\
(27.8 \%) \\
\end{array}$ & $\begin{array}{l}31 \\
(57.4 \%) \\
\end{array}$ & $\begin{array}{l}8 \\
(14.8) \\
\end{array}$ & & $53 / 54(98 \%)$ & $\begin{array}{l}\text { i) } 1 / 12 \\
\text { (8.3\%) } \\
\text { ii) } \mathrm{NR}\end{array}$ & $\begin{array}{l}53 / 54 \\
(98.1 \%) \\
\end{array}$ & $\begin{array}{l}.1 \\
\text { (Range 1-4) }\end{array}$ & $\begin{array}{l}16.2 \\
\text { (Range 8-32) } \\
\end{array}$ & $12 / 54(22.2 \%)$ & $\begin{array}{l}\text { i) } 11 / 12(92 \%) \\
\text { ii) } N R\end{array}$ & NR \\
\hline $\begin{array}{l}\text { Jeschke et al } \\
2012[31]\end{array}$ & $\begin{array}{l}\text { ePLND + } \\
\text { presacral }\end{array}$ & $13(50 \%)$ & $13(50 \%)$ & - & $\begin{array}{l}5 \\
(19.2 \%)\end{array}$ & & $\begin{array}{l}4 \\
(15.2 \%)\end{array}$ & NR & 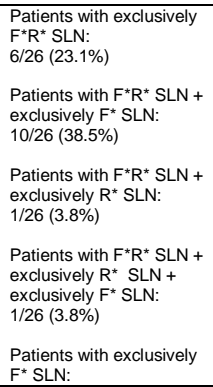 & $\begin{array}{l}\text { i) } 1 / 2 \\
\text { (50\%) } \\
\text { ii) } \mathrm{NR}\end{array}$ & $\begin{array}{l}\text { Overall } \\
\text { ICG } \\
\text { detection: } \\
202 / 26 \\
(76.9 \%) \\
\text { Overall } \\
909 \text { TC } \\
\text { detection: } \\
8 / 26 \\
(30.8 \%) \\
\text { Combinati } \\
\text { on of both } \\
\text { modalities: } \\
2126 \\
(80.8 \%)\end{array}$ & $\begin{array}{l}10 \\
\text { (Range 0-36) }\end{array}$ & $\begin{array}{l}22 \\
\text { (Range 11- } \\
\text { 36) }\end{array}$ & $2 / 26(7.7 \%)$ & i) $1 / 2(50 \%)$ & $\begin{array}{l}\text { i) } 0.4 \% \text { (one solitary } \\
\text { miicrometastasis) } \\
\text { iii) } 0 \% .2 \%\end{array}$ \\
\hline
\end{tabular}


ACCEPTED MANUSCRIPT

\begin{tabular}{|c|c|c|c|c|c|c|c|c|c|c|c|c|c|c|c|c|}
\hline & & & & & & & & & $3 / 26(11.5 \%)$ & & & & & & & \\
\hline $\begin{array}{l}\text { Joniau et al } 2013 \\
\text { [34] }\end{array}$ & sePLND & $\begin{array}{l}32 \\
(43.2 \%)\end{array}$ & $\begin{array}{l}39 \\
(52.7 \%)\end{array}$ & $\begin{array}{l}3 \\
(4.1 \%)\end{array}$ & - & $\begin{array}{l}42 \\
(56.7 \%)\end{array}$ & $\begin{array}{l}32 \\
943.2 \%)\end{array}$ & $\begin{array}{l}73 / 74(98.6 \%) \\
74 \% \text { bilateral visualisation }\end{array}$ & $71 / 74$ (95.9\%) & $\begin{array}{l}\text { i) NR } \\
\text { iii } 45 / 91 \\
(49.5 \%)\end{array}$ & $\begin{array}{l}73 / 74 \\
(98.6 \%)\end{array}$ & $\begin{array}{l}4 \\
\text { (IQR 2.25-6) }\end{array}$ & $\begin{array}{l}21 \\
\text { (IQR 16-27) }\end{array}$ & $34 / 74(46 \%)$ & $\begin{array}{l}\text { i) NR } \\
\text { ii) } 46 / 91(50.5 \%)\end{array}$ & NR \\
\hline $\begin{array}{l}\text { Manny et al } 2014 \\
{[28]}\end{array}$ & $\begin{array}{l}\text { ePLND + common } \\
\text { iliacs }\end{array}$ & $29(58 \%)$ & & & - & - & - & ter & $38 / 50(76 \%)$ & $\begin{array}{l}38(50) \\
(76 \%)\end{array}$ & $\begin{array}{l}\text { i) } 0 / 4(0 \%) \\
\text { ii) NR }\end{array}$ & NR & 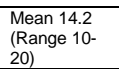 & $4 / 50(8 \%)$ & $\begin{array}{l}\text { i) } 4 / 4(100 \%) \\
\text { ii) } 6 / 6(100 \%)\end{array}$ & $\mathrm{NR}$ \\
\hline $\begin{array}{l}\text { Winter et al } 2014 \\
{[12]}\end{array}$ & ePLND & $\begin{array}{l}798 \\
(64.9 \%)\end{array}$ & $\begin{array}{l}389 \\
(31.7) \%\end{array}$ & $\begin{array}{l}42 \\
(3.45 \%)\end{array}$ & $\begin{array}{l}251 \\
(20.6 \%)\end{array}$ & $\begin{array}{l}900 \\
(74 \%)\end{array}$ & $\begin{array}{l}66 \\
(5.4 \%)\end{array}$ & NR & 1227/1229 (99.8\%) & $\begin{array}{l}\text { i) } 5 / 2100 \\
\text { (2.4\%) } \\
\text { ii) } N R\end{array}$ & $\begin{array}{l}1227 / 1229 \\
(99.8 \%)\end{array}$ & $\begin{array}{l}6 \\
\text { (IQR 4-8) }\end{array}$ & $\begin{array}{l}10 \\
(\text { IQR 7-13) }\end{array}$ & $210 / 1229(17.1 \%)$ & $\begin{array}{l}\text { i) } 205 / 210(97.6 \%) \\
\text { ii) } N R\end{array}$ & $\begin{array}{l}\text { ii) } 19 \% \\
\text { ii) } 13.8 \% \\
\text { iii) } 17.6 \%\end{array}$ \\
\hline $\begin{array}{l}\text { Rousseau et al } \\
2014[14]\end{array}$ & $\begin{array}{l}\text { ePLND + common } \\
\text { iliacs }\end{array}$ & $\begin{array}{l}78 \\
(50.6 \%)\end{array}$ & $\begin{array}{l}76 \\
(49.4 \%)\end{array}$ & . & $\begin{array}{l}37 \\
(24.0 \%)\end{array}$ & $\begin{array}{l}\begin{array}{l}108 \\
(70.1 \%)\end{array} \\
\end{array}$ & $\stackrel{9}{(5.8 \%)}$ & $\begin{array}{l}191 / 203(94 \%) \\
78 \% \text { bilateral visualisation }\end{array}$ & 195/203 (96.1\%) & $\begin{array}{l}\text { i) } 3 / 35 \\
(8.6 \%) \\
\text { ii) NR }\end{array}$ & $\begin{array}{l}199 / 203 \\
(98.2 \%)\end{array}$ & $\begin{array}{l}5.6 \\
\text { (SDะ3.7) }\end{array}$ & $\begin{array}{l}28.3 \\
(\mathrm{SD} \pm 10.2)\end{array}$ & $35 / 203(17.2 \%)$ & $\begin{array}{l}\text { i) } 32 / 35 \text { (91.4\%) } \\
\text { ii) } \mathrm{NR}\end{array}$ & 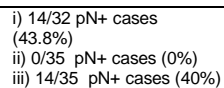 \\
\hline $\begin{array}{l}\text { Staník et al } 2014 \\
\text { [38] }\end{array}$ & ePLND & $\begin{array}{l}29 \\
(36.3 \%)\end{array}$ & $\begin{array}{l}50 \\
(62.5 \%)\end{array}$ & ${ }_{(1.25 \%)}^{1}$ & $\begin{array}{l}4 \\
(5 \%)\end{array}$ & $\begin{array}{l}59 \\
(73.8 \%)\end{array}$ & $\begin{array}{l}17 \\
(21.3 \%)\end{array}$ & $\begin{array}{l}85 \% \text { of cases } \\
53 \% \text { bilateral visualisation }\end{array}$ & $98 \%$ of cases & $\begin{array}{l}\text { i) } 3 / 32 \\
\text { (i.4\%) } \\
\text { ii) } \mathrm{NR}\end{array}$ & NR & ${ }_{\text {(IQR 3-5) }}^{4}$ & $\begin{array}{l}17 \\
\text { (IQR 14-20) }\end{array}$ & $32 / 80(40 \%)$ & $\begin{array}{l}\text { i) } 29 / 32(90.6 \%) \\
\text { ii) } \mathrm{NR}\end{array}$ & $\begin{array}{l}\text { i) } \mathrm{NR} \\
\text { ii) } \mathrm{NR} \\
\text { iii } 1 / 232 \mathrm{pN}+\text { cases } \\
(37.5 \%)\end{array}$ \\
\hline $\begin{array}{l}\text { Kleinjan et at } 2014 \\
{[7]}\end{array}$ & ePLND & $\begin{array}{l}22 \\
(55 \%)\end{array}$ & $\begin{array}{l}18 \\
(45 \%)\end{array}$ & - & $\begin{array}{l}4 \\
(10 \%)\end{array}$ & $\begin{array}{l}28 \\
(70 \%)\end{array}$ & $8(20 \%)$ & $\begin{array}{l}38 / 40(95 \%) \\
82.5 \% \text { bilateral visualisation }\end{array}$ & $\begin{array}{l}\text { ICG: } \\
\text { 1) } 63.7 \% \\
\text { 2) } 85.5 \% \\
\text { 3) } 93.5 \% \\
\text { 99m TC: } \\
\text { 1) } 100 \% \\
\text { 2) } 100 \% \\
\text { 3) } 100 \% \\
\end{array}$ & $\begin{array}{l}\text { i) } 2 / 8 \\
\text { (25\%) } \\
\text { iit } 1 / 632 \\
\text { (50\%) }\end{array}$ & $\begin{array}{l}40 / 40 \\
(100 \%)\end{array}$ & ${ }_{\text {(IQR 2.3-5.0) }}^{4}$ & & $8 / 40(20 \%)$ & $\begin{array}{l}\text { i) } 6 / 8(75 \%) \\
\text { ii) } 16 / 32(50 \%)\end{array}$ & NR \\
\hline $\begin{array}{l}\text { Winter et al } 2014 \\
{[24]}\end{array}$ & $\begin{array}{l}\text { ePLND + common } \\
\text { iliacs }\end{array}$ & $\begin{array}{l}9 \\
(47.4 \%)\end{array}$ & $\begin{array}{l}9 \\
(47.4 \%)\end{array}$ & $\begin{array}{l}1 \\
(5.3 \%)\end{array}$ & - & $\begin{array}{l}15 \\
(78.9 \%)\end{array}$ & $\begin{array}{l}4 \\
(21.1 \%)\end{array}$ & - & $17 / 19(89.5 \%)$ & $\begin{array}{l}\text { ii) } 0 / 6(6 \%) \\
\text { iii) } 0 / 15 \\
(0 \%)\end{array}$ & $\begin{array}{l}17 / 19 \\
(89.5 \%)\end{array}$ & (II & (I) & $7 / 19(36.8 \%)^{* *}$ & $\begin{array}{l}\text { i) } 6 / 6(100 \%) \\
\text { ii) } 15 / 15(100 \%)\end{array}$ & NR \\
\hline $\begin{array}{l}\text { Hruby et al } 2015 \\
{[26]}\end{array}$ & sePLND & $\begin{array}{l}13 \\
(34.2 \%)\end{array}$ & $\begin{array}{l}11 \\
(28.9 \%)\end{array}$ & $\begin{array}{l}14 \\
(36.8 \%)\end{array}$ & $\begin{array}{l}8 \\
(21.1 \%)\end{array}$ & $\begin{array}{l}20 \\
(52.6 \%)\end{array}$ & $\begin{array}{l}10 \\
(26.3 \%)\end{array}$ & - & $37 / 38(97.4 \%)$ bilaterally & 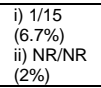 & $\begin{array}{l}37 / 38 \\
(97.4 \%)\end{array}$ & 12 & 18 & $15 / 38(39.5 \%)$ & $\begin{array}{l}\text { i) } 14 / 15(93.3 \%) \\
\text { ii) NR/NR (97.7\%) }\end{array}$ & $\begin{array}{l}\text { i) } 2 / 15 \mathrm{pN}+\text { cases }(13.3 \%) \\
\text { ii) } \mathrm{NR} \\
\text { iii) } 2 / 15 \mathrm{pN}+\text { cases }(26.7 \%)\end{array}$ \\
\hline $\begin{array}{l}\begin{array}{l}\text { Yuen et al } 2015 \\
{[29]}\end{array} \\
\end{array}$ & ePLND & $\begin{array}{l}51 \\
(79.7 \%) \\
\end{array}$ & $\begin{array}{l}13 \\
(20.3 \%) \\
\end{array}$ & & $\begin{array}{l}1 \\
(1.6 \%) \\
\end{array}$ & $\begin{array}{l}45 \\
(70.3 \%) \\
\end{array}$ & $\begin{array}{l}18 \\
(28.1 \%) \\
\end{array}$ & - & $64 / 66(97 \%)$ & $\begin{array}{l}\text { i) } 0 / 6(0 \%) \\
\text { ii) } 0 / 11 \\
(0 \%)\end{array}$ & & & $\begin{array}{l}18 \\
\text { (Range 5-33) } \\
\end{array}$ & $6 / 66(9.1 \%)$ & $\begin{array}{l}\text { i) } 6 / 6(100 \%) \\
\text { ii) } 11 / 11(100 \%)\end{array}$ & $\mathrm{NR}$ \\
\hline $\begin{array}{l}\text { Kleinjan et al } 2016 \\
{[6]}\end{array}$ & ePLND & $\begin{array}{l}43 \\
(78.2 \%)\end{array}$ & $\begin{array}{l}10 \\
(18.2 \%)\end{array}$ & $\begin{array}{l}2 \\
(3.6 \%)\end{array}$ & $\begin{array}{l}7 \\
(12.7 \%)\end{array}$ & $\begin{array}{l}37 \\
(67.3 \%)\end{array}$ & $\begin{array}{l}11 \\
(20 \%)\end{array}$ & $\begin{array}{l}55 / 55(100 \%) \\
81.8 \% \text { bilateral visualisation }\end{array}$ & $148 / 184$ nodes $(80.4 \%)$ & $\begin{array}{l}\text { i) } 1 / 14 \\
\text { (7.1\%) } \\
\text { ii) } \mathrm{NR}\end{array}$ & & $\begin{array}{l}4 \\
\text { (IQR 2-5) }\end{array}$ & $\begin{array}{l}16 \\
\text { (IQR 12-20) }\end{array}$ & $14 / 55(25.5 \%)$ & 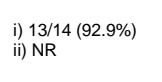 & NR \\
\hline $\begin{array}{l}\text { Nguyen et al } 2016 \\
{[30]}\end{array}$ & sePLND & $\begin{array}{l}19 \\
(45.2 \%)\end{array}$ & $\begin{array}{l}23 \\
(54.8 \%)\end{array}$ & - & $\begin{array}{l}5 \\
(11.9 \%)\end{array}$ & $\begin{array}{l}24 \\
(57.1 \%)\end{array}$ & $\begin{array}{l}13 \\
(40.0 \%)\end{array}$ & - & $\begin{array}{l}42 / 42(100 \%) \\
\text { bilateral }\end{array}$ & $\begin{array}{l}\text { i) } 1 / 5 \\
(20 \%) \\
\text { iii) } 13 / 29 \\
(44.8 \%)\end{array}$ & $\begin{array}{l}42 / 142 \\
(100 \%) \\
\text { bilateral }\end{array}$ & $\begin{array}{l}15 \\
\text { (IQR 10-20) }\end{array}$ & $\begin{array}{l}35 \\
\text { (IQR 26-42) }\end{array}$ & $\begin{array}{l}\text { Patients receiving } \\
\text { systematic IIG } \\
\text { injections }(n=12) \\
5 / 12(41.7 \%)\end{array}$ & $\begin{array}{l}\text { i) } 4 / 5(80 \%) \\
\text { ii) } 16(29 \%) \\
(55.2 \%)\end{array}$ & $\mathrm{NR}$ \\
\hline
\end{tabular}

Table 4. Outcomes of the studies reporting diagnostic performance of sentinel lymph node dissection at the time of radical surgery for prostate cancer.

Limited pelvic lymph node dissection (obturator), LimPLND; Standard pelvic lymph node dissection (obturator, ext. iliac), sPLND; Extended pelvic lymph node dissection (obturator, ext. iliac, int. iliac), ePLND; Super-extended pelvic lymph node dissection (obturator, ext. iliac, int. iliac, common iliac, presacral), sePLND;

Sentinel lymph node, SLN; Lymph node invasion, LNI; False-negative rate (False negative/LNI), FNR; Interquartile range, IQR; Fluorescent node, F*; Radioactive node, $\mathbf{R}^{*}$; Nodal metastasis, $\mathbf{p N +}$.

${ }^{*}$ Two obstructed metastatic nodes in two patients

${ }^{* *}$ One patient with no visualisation 
Tracer-guided nodal dissection is feasible and safe in prostate cancer.

There are multiple variable landing sites for nodal metastases from the prostate.

Tracers do not specifically delineate the lymphatic drainage of malignant foci.

Patients require back-up lymphadenectomy to avoid missing nodal metastases.

There is little evidence on the long-term oncological outcomes of the technique. 